SUMMARY

Rabbit pups were maintained from birth either on a high fat, low protein diet or on a low fat, high protein diet for as long as 10 days. Rates of palmityl coenzyme A oxidation, glutamate + malate-supported respiration, and cytochrome oxidase activity in heart and liver homogenates were the same in both groups and similar in all respects to rates observed in mother-fed animals. In view of these findings, the hypothesis that the amount of lipid in the postnatal diet influences the ability to oxidize long chain fatty acids must be re-evaluated. It seems likely that other perinatal stimuli may be more important than diet in regulating oxidative energy metabolism to ensure survival during this critical transition period.

\section{REFERENCES AND NOTES}

1. Aas, M., and Daae, L. N.: Fatty acid activation and acyl transfer in organs from rats in different nutritional states. Biochim. Biophys. Acta, 239: 208 (1971).

2. Aprille, J. R., and Rulfs, J.: A convenient neonatal model for developmental studies requiring artificial diets. Biol. Neonate (In press.)

3. Aprille, J. R., and Rulfs, J.: Dietary lipid and postnatal development. I. A model for neonatal studies requiring high and low fat diets from birth. Pediat. Res. 10: 978 (1976).

4. Augenfeld, J., and Fritz, I.: Carnitine palmityltransferase activity in fatty acid oxidation by livers from fetal and neonatal rats. Can. J. Biochem., 48: 288 (1970).

5. Bieber, L. L., Markwell, M. A. K., Blair, M., and Helmrath, T. A.: Studies on the development of carnitine palmitoyltransferase and fatty acid oxidation in liver mitochondria of neonatal pigs. Biochim. Biophys. Acta, 326: 145 (1973).

6. Bremer, J., and Norum, K. R.: Palmityl CoA:carnitine O-palmityltransferase in the mitochondrial oxidation of palmityl CoA. Europ. J. Biochem., l: 427 (1967).

7. Breuer, E., Barta, E., Zlatos, L., and Pappora, E.: Developmental changes of myocardial metabolism. II. Myocardial metabolism of fatty acids in the early postnatal period of dogs. Biol. Neonat., 12: 54 (1968).

8. Chen, R. F.: Removal of fatty acids from serum albumin by charcoal treatment. J. Biol. Chem., 242: 173 (1967)

Copyright $\odot 1976$ International Pediatric Research Foundation, Inc.
9. Hoppel, C. L., and Tomec, R. J.: Carnitine palmityltransferase: Location of two enzymatic activities in rat liver mitochondria. J. Biol. Chem., 247: 832 (1972).

10. Lockwood, E., and Bailey, E.: Fatty acid utilization during development of the rat. Biochem. J., 120: 49 (1970).

11. Lowry, O. H., Rosebrough, N. J., Farr, A. J., and Randall, R. J.: Protein measurement with Folin phenol reagent. J. Biol. Chem., 193: 265 (1951).

12. McGarry, J. D., Meier, J. M., and Foster, D. W.: The effects of starvation and refeeding on carbohydrate and lipid metabolism in vivo in the perfused rat liver. J. Biol. Chem., 248: 270 (1973).

13. Novak, M., Penn-Walker, D., and Monkus, E. F.: Oxidation of fatty acids by mitochondria obtained from newborn subcutaneous (white) adipose tissue. Biol. Neonate, 25: 95 (1975).

14. Pande, S. V.: A mitochondrial carnitine acylcarnitine translocase system. Proc. Nat. Acad. Sci. U.S.A., 72: 883 (1975).

15. Scow, R. O., Mendelson, C. R., Zinder, O., Hamesh, M., and BlanchetteMackie, E. J.: Role of lipoprotein lipase in the delivery of dietary fatty acids to lactating mammary tissue. In: C. Galli, G. Jacini, and A. Pecile: Dietary Lipids and Postnatal Development (Raven Press, New York, 1973).

16. Shephered, O., Yates, D. W., and Garland, P. B.: The rate-limiting step in the oxidation of palmitate or palmityl-coenzyme $\mathrm{A}$ by rat-liver mitochondria. Biochem. J., 98: 3c (1966).

17. Warshaw, J. B.: Cellular energy metabolism during fetal development. IV. Fatty acid activation, acyl transfer and fatty acid oxidation during development of the chick and rat. Develop.Biol., 28: 537 (1972).

18. Warshaw, J. B., and Terry, M. L.: Cellular energy metabolism during fetal development. II. Fatty acid oxidation by the developing heart. J. Cell Biol., 44: $354(1970)$.

19. Widdowson, E.: Changes in the composition of the body at birth and their bearing on function and food requirements. In: J. Jonxis, $\mathrm{H}$. Visser, and J. Troelstra: Nutritia Symposium on the Adaptation of the Newborn Infant to Extrauterine Life (Stenfert Kroese N.V., Leyden, 1964)

20. Wittels, B., and Bressler, R.: Lipid metabolism in the newborn heart. J. Clin. Invest., 44: 1639 (1965).

21. Wood, J. M.: Carnitine palmityltransferase in neonatal and adult heart and liver mitochondria. J. Biol. Chem., 250: 3062 (1975).

22. The technical assistance of Jill Rulfs is gratefully acknowledged

23. This study was supported by grants from the United States Public Health Service (NIH HD08600) and the Charles H. Hood Foundation.

24. Requests for reprints should be addressed to: J. R. Aprille, Ph.D., Shriner's Burns Institute at the Massachusetts General Hospital, 50 Blossom St., Boston, Mass. 02114 (USA).

25. Accepted for publication June $28,1976$.
Chemotaxis lysosomal hydrolases mannosidosis $\alpha$-mannosidosis

neutrophil

$\mathrm{Zn}$-dependent enzymes

\title{
Mannosidosis: Clinical, Morphologic, Immunologic, and Biochemical Studies
}

\author{
ROBERT J. DESNICK, ${ }^{(58)}$ HARVEY L. SHARP, GREGORY A. GRABOWSKI, RICHARD D. \\ BRUNNING, PAUL G. QUIE, JOO H. SUNG, ROBERT J. GORLIN, AND JUSTUS U. IKONNE
}

Departments of Pediatrics, Genetics and Cell Biology, Laboratory Medicine and Pathology, Neurology, Oral Pathology, and the Dight Institute for Human Genetics, University of Minnesota, Minneapolis, Minnesota, USA

\section{Extract}

The primary metabolic defect in mannosidosis is the deficiency of the acidic $\alpha$-mannosidase $A$ and $B$ activities which results in the lysosomal accumulation of mannose-rich substrates. Our studies demonstrate that the enzymatic diagnosis of suspect homozygotes can be made reliably using plasma, isolated leukocytes, or cultured skin fibroblasts assayed carefully at the appropriate acidic $\mathrm{pH}$.

Immunologic studies of a mannosidosis homozygote revealed significant abnormalities of neutrophil function; these included a depressed chemotactic responsiveness and impaired phagocytosis of bacteria. Lymphocyte transformation studies showed a $20 \%$ of normal response to purified phytohemagglutinin and a $25 \%$ of normal response to concanavalin $A$.

Three major components of $\alpha$-mannosidase activity in normal human liver were resolved by ion exchange chromatography on DEAE-cellulose and electrophoresis on cellulose acetate gels. Electrophoresis of the liver extract from homozygote $I$ with mannosidosis revealed only one band of activity which coelectrophoresed with the $\alpha$-mannosidase $C$ isozyme partially purified from normal liver. However, ion exchange chromatography revealed the presence of residual hepatic acidic activities; the residual $A$ 
isozyme was eluted in a position corresponding to that of normal $\alpha$-mannosidase $\mathbf{A}$ whereas the residual $\mathbf{B}$ activity was eluted at a slightly more electronegative position than that of normal $B$ isozyme.

The apparent $K_{m}$ values for $\alpha$-mannosidase activity as determined from Lineweaver-Burk plots were $1.1 \mathrm{mM}$ for normal liver and $0.9 \mathrm{mM}$ for normal leukocytes. In contrast, the residual activity in these sources from homozygote $I$ could not be saturated within the solubility range of the substrate; the apparent $K_{m}$ value was estimated at $15.4 \mathrm{mM}$ in liver extracts.

Zinc significantly lowered the apparent $K_{m}$ value of the acidic activity in normal liver (from 1.2 to $0.24 \mathrm{mM}$ ), whereas this metallic ion had little effect on the values for mannosidosis hepatic activity (from 15.4 to $12.3 \mathrm{mM}$ ). Unlike zinc, cobalt had its major effect on the acidic activity in the mannosidosis liver extract, lowering the apparent $K_{m}$ from 15.4 to $3.9 \mathrm{mM}$, whereas the apparent $K_{m}$ fot the normal activity was increased from 1.2 to $1.9 \mathrm{mM}$. The residual acidic activities were markedly stimulated by zinc in both leukocytes $(\sim 300 \%)$ and plasma $(\sim 400 \%)$ from the homozygotes and to a lesser extent in those sources from normal individuals. In contrast, cobalt enhanced the residual acidic activities in leukocytes $(\sim 500 \%)$ and plasma $(\sim 200 \%)$ from the homozygotes while inhibiting these acidic activities $(78.9 \%$ and $47.7 \%$, respectively) in normal individuals.

\section{Speculation}

The susceptibility of homozygotes with mannosidosis to severe recurrent infections may be the direct consequence of impaired leukocyte membrane recognition processes resulting from the defective catabolism of substrates with $\alpha$-D-mannose residues. The metabolic defect in mannosidosis presumably results from a structural gene mutation which alters the kinetic and metal binding properties of the lysosomal $\alpha$-mannosidase activities. Appropriate metal cation supplementation may stimulate the residual activity of the mutant isozymes and provide an effective therapeutic approach to patients with this inborn error of metabolism.

Mannosidosis, a systemic lysosomal storage disease first described by Öckerman (33), is characterized by psychomotor retardation, a facial dysmorphia resembling that of the Hurler syndrome, dysostosis multiplex, hepatosplenomegaly, hearing loss, recurrent infections, and autosomal recessive inheritance. The primary metabolic defect responsible for these manifestations is the deficiency of the acidic $\alpha$-mannosidase A and B activities ( $\alpha$-D-mannoside mannohydrolase, EC. 3.2.1.24) (9, 29, 35), which results in the lysosomal accumulation of mannose-rich oligosaccharides in neural $(34)$ and visceral tissues $(1,33)$ and in the urine $(1,31,32,46)$ of affected homozygous patients. Presumably this enzymatic defect also leads to the accumulation of other pathogenic glycoconjugate substrates with terminal $\alpha$-mannosyl residues as evidenced by the recent finding of abnormal glycopeptides, rich in mannose, in cultured skin fibroblasts from a homozygote with mannosidosis (47).

Since Öckerman's original report in 1967 (33), only 18 patients with this lysosomal storage disease have been described $(1,2,6,14$, $24,26,27,32,46)$. We have seen five patients in two unrelated families at the University of Minnesota Hospitals during the past 4 years. The major clinical and laboratory findings of our cases and those in the literature have been summarized in Table 1 . In this report, we describe the clinical course of a previously unreported patient (homozygote $I$ ), who expired at age $3 \frac{1}{2}$ years, and emphasize the morphologic and laboratory features of this disorder. In addition, we report the results of our investigations to further characterize the molecular pathology of this disorder including correlative studies of the ultrastructural, enzymatic, and immunologic defects in mannosidosis.

\section{CASE REPORT}

Homozygote 1 , a $22 / 12$ year-old Caucasian female $(M L ; U M H$ 1194722), was initially referred to the University of Minnesota
Hospitals for evaluation of recurrent infections (Fig. 1). She was the firstborn (June 6, 1971) of unrelated parents following an uncomplicated pregnancy, labor, and delivery. Birth weight was $3.2 \mathrm{~kg}$ and the neonatal and early infancy periods were unremarkable. At 6 months of age she was noted to have a greater occipital-frontal circumference than chest circumference and was hospitalized for the evaluation of suspected hydrocephalus. At that time, the diagnosis of arrested hydrocephalus was made. During the next 19 months she had chronic otitis media and eight episodes of upper respiratory tract infections, four of which required hospitalization. In addition, a mild developmental delay was noted; she rolled over at 4 months, sat at 8 months, crawled at 12 months, and walked with and without assistance at 18 and 23 months, respectively.

On admission, physical examination revealed a well developed 22/12-year-old female with a prominent forehead and a mild facial dysmorphia resembling that of the Hurler syndrome. Her height was $91.5 \mathrm{~cm}(+1 \mathrm{SD})$, weight $14.9 \mathrm{~kg}(+1.7 \mathrm{SD})$, and occipitalfrontal circumference $54.0 \mathrm{~cm}(+3 \mathrm{SD})$. Pertinent physical findings included frontal bossing, dull gray tympanic membranes, and hepatosplenomegaly. The liver edge was firm, smooth, and palpable $5 \mathrm{~cm}$ below the right costal margin and the splenic tip was palpable $2 \mathrm{~cm}$ below the left costal margin. In addition, there was a small reducible umbilical hernia, unusually thick-feeling skin without lesions, and prominent lymphadenopathy. Cardiac examination and EKG were normal. Neurologically, she had normal motor strength, tone, and sensory response. Cranial nerves were grossly intact except for a 70-dB hearing loss. Cerebellar function was intact, although her gait was broad-based for age. Electroencephalographic studies were normal. Denver Developmental Screening indicated gross motor, fine motor, language, and personal-social skills at $13,21,6$, and 14 months of age, respectively. The delay in language development presumably was related to the severe hearing loss.

Radiologic examination revealed chronic pulmonary infiltrates consistent with repeated infections. Extensive bony abnormalities compatible with dysostosis multiplex were present, including a "J-shaped" sella, a hypoplastic L2 lumbar vertebra with anterior beaking, tapered proximal metacarpals, mild flaring of the iliac wings, and extensive sclerosis of the cranial vautt and particularly of the skull base. No corneal or lenticular opacities were seen by slit lamp microscopy; normal discs, retinae, and maculae were noted on funduscopic examination.

Clinical laboratory studies included normal blood-urea-nitrogen, creatinine, sodium, potassium, chloride, bicarbonate, calcium, phosphorus, bilirubin, serum glutamic oxalacetic transferase, alkaline phosphatase, serum protein electrophoresis, cholesterol, triglycerides, and total phospholipids. Sweat chlorides were normal and the quantitative immunoglobulins were IgA, 157 $\mathrm{mg} / 100 \mathrm{ml}$ (normal range for age, 34- $109 \mathrm{mg} / 100 \mathrm{ml}$ ); IgG, 940 $\mathrm{mg} / 100 \mathrm{ml}(557-1,100 \mathrm{mg} / 100 \mathrm{ml})$; and $\mathrm{IgM}, 127 \mathrm{mg} / 100 \mathrm{ml}$ $(40-119 \mathrm{mg} / 100 \mathrm{ml})$. Coagulation studies were within normal limits. The hemoglobin was $11.5 \mathrm{~g} / 100 \mathrm{ml}$ and the leukocyte count was $9,200 / \mathrm{mm}^{3}$ with a normal differential. On examination of a peripheral smear, approximately $90 \%$ of the lymphocytes were vacuolated. The urinary metabolic screen was normal, including a Berry spot test.

Special diagnostic studies included quantitative urinary amino acids and mucopolysaccharides which were within normal limits. Bone marrow biopsy revealed foamy appearing macrophages similar to those seen in Niemann-Pick disease as well as vacuolated lymphocytes. No inclusion bodies were observed by phase microscopy in cultured skin fibroblasts. Ultrastructural examination of hepatic tissue obtained by percutaneous biopsy showed numerous, enlarged lysosomes containing amorphous mucopolysaccharide-or glycoprotein-like material. Assays of various lysosomal hydrolase activities were performed; the demonstration of deficient acidic $\alpha$-mannosidase activity in plasma, isolated peripheral leukocytes, and cultured skin fibroblasts established the diagnosis of mannosidosis.

At $3 \frac{1}{2}$ years of age, the patient was transported to the 
Table 1. Major clinical and laboratory features of enzymatically confirmed homozygotes with mannosidosis

\begin{tabular}{|c|c|c|c|c|c|c|c|c|c|c|c|c|}
\hline Author and reference & $\begin{array}{c}\text { Case } \\
\text { no. }\end{array}$ & Sex & $\begin{array}{l}\text { Facial } \\
\text { dysmor- } \\
\text { phology }\end{array}$ & $\begin{array}{c}\text { Dysostosis } \\
\text { multiplex }\end{array}$ & $\begin{array}{l}\text { Mental } \\
\text { retar- } \\
\text { dation }\end{array}$ & $\begin{array}{l}\text { Hearing } \\
\text { loss }\end{array}$ & $\begin{array}{c}\text { Corneal/ } \\
\text { lenticular } \\
\text { opacities }\end{array}$ & $\begin{array}{l}\text { Hepato- } \\
\text { spleno- } \\
\text { megaly }\end{array}$ & $\begin{array}{l}\text { Vacuo- } \\
\text { lated } \\
\text { lymph- } \\
\text { ocytes }\end{array}$ & $\begin{array}{c}\text { Decreased } \\
\text { serum } \\
\text { IgG }\end{array}$ & $\begin{array}{l}\text { Recur- } \\
\text { rent } \\
\text { infec- } \\
\text { tions }\end{array}$ & $\begin{array}{c}\text { Mucopoly- } \\
\text { saccha- } \\
\text { riduria }\end{array}$ \\
\hline Ockerman $(33,34)$ & 1 & $\mathrm{M}$ & + & + & + & & + & + & + & + & + & - \\
\hline \multirow[t]{3}{*}{ Autio et al. (1) } & 2 & $\mathrm{M}$ & + & + & + & + & - & - & + & + & + & - \\
\hline & 3 & $\mathrm{M}$ & + & + & + & - & + & - & + & + & + & - \\
\hline & 4 & $\mathrm{M}$ & + & + & + & - & + & - & + & + & + & - \\
\hline \multirow[t]{2}{*}{ Norden et al. (32) } & 5 & $\mathrm{~F}$ & + & + & + & & + & + & + & & & \pm \\
\hline & 6 & $F$ & + & + & + & & + & + & + & & + & \pm \\
\hline Tsay et al. (46) & 7 & $\mathbf{M}$ & + & + & - & & - & + & - & & & - \\
\hline \multirow[t]{5}{*}{ Farriaux et al. (14) } & 8 & $\mathrm{M}$ & + & + & - & + & - & & + & & + & - \\
\hline & 9 & $\mathbf{M}$ & + & + & + & & - & & + & & & - \\
\hline & 10 & M & + & + & + & & - & & + & & & - \\
\hline & 11 & $\mathrm{~F}$ & + & + & & & - & & + & & & - \\
\hline & 12 & $\mathrm{M}$ & + & + & & & - & & + & & & - \\
\hline \multirow[t]{2}{*}{ Loeb et al. $(26,27)$} & 13 & $\mathrm{~F}$ & + & - & + & + & - & - & + & & + & - \\
\hline & 14 & M & + & \pm & + & + & - & - & + & & + & + \\
\hline \multirow[t]{3}{*}{ Booth et al. (6) } & 15 & $\mathrm{~F}$ & + & \pm & + & + & - & - & & & - & - \\
\hline & 16 & $\mathrm{~F}$ & + & \pm & + & + & - & - & & & - & - \\
\hline & 17 & M & + & \pm & + & + & - & - & & & - & - \\
\hline Aylsworth et al. (2) & 18 & $\mathrm{M}$ & + & + & + & - & + & + & + & - & + & - \\
\hline \multicolumn{13}{|l|}{ Present cases } \\
\hline Homozygote I & 19 & $\mathrm{~F}$ & + & + & + & + & - & + & + & + & + & - \\
\hline Homozygote 2 & 20 & $\mathrm{M}$ & + & + & + & + & + & - & + & - & + & - \\
\hline Homozygote 3 & 21 & M & + & + & + & + & + & - & + & - & + & - \\
\hline Homozygote 4 & 22 & $\mathrm{~F}$ & + & + & + & + & + & - & + & - & + & - \\
\hline Homozygote 5 & 23 & $\mathrm{~F}$ & + & + & + & + & + & - & + & - & - & - \\
\hline Total & 23 & $\begin{array}{l}14 \mathrm{M} / \\
9 \mathrm{~F}\end{array}$ & $23 / 23$ & $22 / 23$ & $19 / 21$ & $12 / 15$ & $10 / 23$ & $6 / 18$ & $19 / 20$ & $5 / 10$ & $13 / 17$ & $3 / 23$ \\
\hline
\end{tabular}

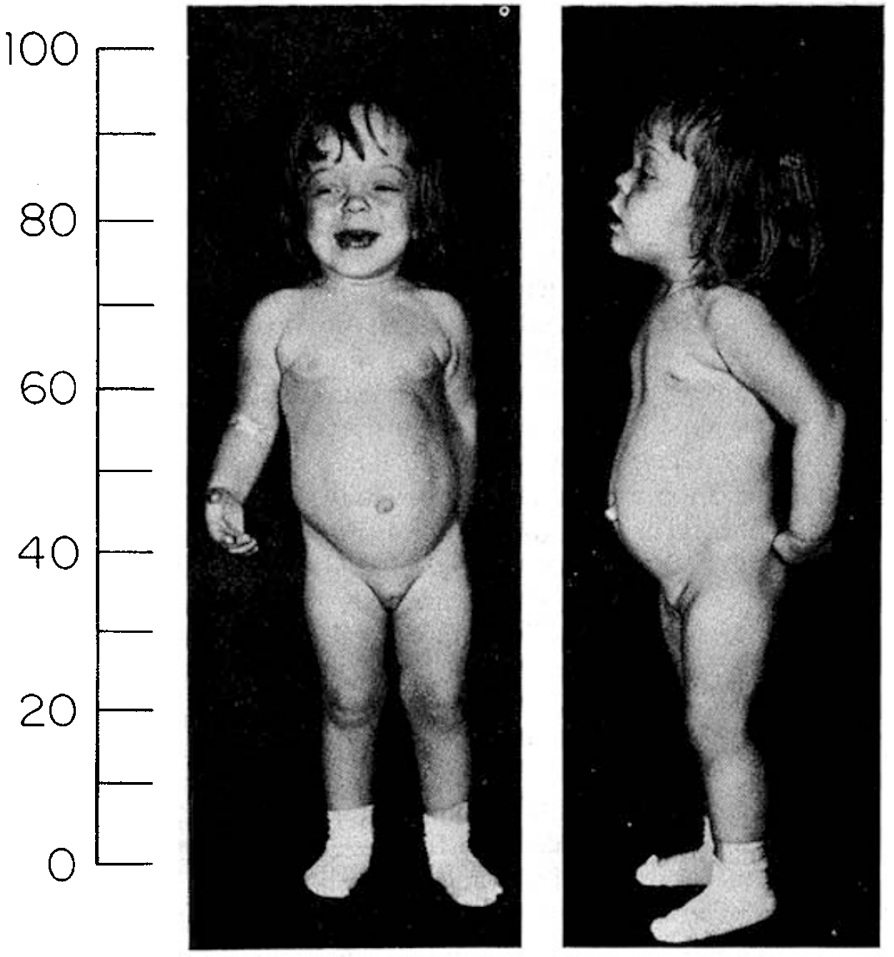

Fig. 1. Homozygote $l$ at the age of $2 \frac{1}{2}$ years old.

University of Minnesota Hospitals after 4 months of almost continual hospitalization elsewhere for recurrent pneumonitis, otitis, and upper respiratory tract infections. Quantitative immunoglobulins on admission were $\mathrm{IgA}, 105 \mathrm{mg} / 100 \mathrm{ml}$ (normal range for age, $47-129 \mathrm{mg} / 100 \mathrm{ml}) ; \mathrm{IgG}, 576 \mathrm{mg} / 100 \mathrm{ml}(680-1,270$ $\mathrm{mg} / 100 \mathrm{ml}) ; \mathrm{IgM}, 66 \mathrm{mg} / 100 \mathrm{ml}(69-168 \mathrm{mg} / 100 \mathrm{ml}) ; \mathrm{IgE}, 18$ $\mathrm{ng} / \mathrm{ml}(21-198 \mathrm{ng} / \mathrm{ml})$. She was anergic on skin testing to PPD, streptokinase/streptodornase, Candida, and mumps antigens. During this hospitalization she developed severe respiratory distress with nasal flaring, intercostal retraction, diffuse rhonchi, and a temperature of $105^{\circ} \mathrm{F}$. Chest $\mathrm{x}$-ray revealed marked bilateral basilar infiltrates. The respiratory status deteriorated rapidly over a week period despite intensive chemotherapy and respiratory support. She expired from respiratory failure and disseminated intravascular coagulation. Adenovirus type 7 was cultured from urine, stool, and throat cultures obtained before death and from lung tissue obtained at autopsy.

\section{MATERIALS AND METHODS}

\section{MORPHOLOGIC STUDIES}

Routine peripheral blood and bone marrow smears were stained with Wright's-Giemsa. Smears were also subjected to periodic acid-Schiff, Sudan black B, Toluidine blue O, and Oil Red O reactions. Particles of bone marrow were processed for electron microscopy in a manner previously described (8).

Percutaneous liver biopsy was obtained with a 1.6-mm Menghini needle by previously described procedures (41). Neuropathologic studies were carried out on brain tissues obtained at autopsy within $30 \mathrm{~min}$ of death. Liver and brain were fixed for electron microscopy in Millong's buffer containing $1.25 \%$ glutaraldehyde and $1.25 \%$ osmic acid. After $1 \mathrm{hr}$, the tissues were dehydrated in graded alcohols, initially with $70 \%$ ethanol, and propylene oxide and embedded in Epon. Thin sections stained with uranyl acetate and lead citrate were examined in a Phillips 200 electron microscope.

\section{IMMUNOLOGIC STUDIES}

Neutrophil chemotactic assays were performed by the method of Mowat and Baum (30) as modified by Hill et al. (19). Leukocytes 
were separated by gravity sedimentation from heparinized blood, washed, counted, and diluted with balanced salt solution to approximately $2.5 \times 10^{6}$ neutrophils $/ \mathrm{ml}$. Aliquots $(0.4 \mathrm{ml})$ of this suspension were centrifuged onto $5-\mu \mathrm{m}$ Millipore filters in a cytocentrifuge. The filters were placed in a modified Boyden chamber with Escherichia coli bacterial factor as a chemotactant. After a 3-hr incubation, the filters were removed and stained with hematoxylin. The number of neutrophils that migrated completely through each filter in 10 random high power fields (using a 5- by $5-\mathrm{mm}$ reticule) were counted. A chemotactic index was derived by dividing this number by the number of cells $\left(\times 10^{6}\right)$ delivered to the starting side of the filter. Simultaneous control neutrophil chemotaxis assays were performed on the same day using neutrophils from adult laboratory personnel. All assays were done in triplicate and compared with control values. Normal values for this technique were 35-99; the reproducibility among triplicate assays of a given neutrophil sample was $13 \%$ of the mean (19).

For these experiments, a bacterial chemotactic factor produced by the overnight growth of $E$. coli grown in balanced salt solution at $37^{\circ}$ was used. The culture broth was passed through a $0.22-\mu \mathrm{m}$ Millipore filter and this filtrate was then stored at $-70^{\circ}$ in $1-\mathrm{ml}$ ampules. On each test day, the ampules were thawed, diluted 1:20 with balanced salt solution, and used as the chemotactic attractant. Random migration was determined by counting the number of neutrophils which migrated completely through the Millipore filter when balanced salt solution was substituted for the chemotactic factor.

Neutrophil phagocytosis and bacterial killing studies were carried out by the Maaloe method as modified by Quie et al. (39). Neutrophil nitroblue tetrazolium (NBT) reduction was performed by the method of Park et al. (35).

\section{BIOCHEMICAL STUDIES}

Plasma was obtained from heparinized blood by centrifugation at $2,000 \times g$ for $10 \mathrm{~min}$ at $4^{\circ}$. Leukocytes were isolated as previously described $(7,12)$. Liver from the patient and from age-matched control subjects was obtained within 15 min after death and frozen immediately at $-70^{\circ}$ for subsequent analyses.

The acidic ( $\mathrm{pH} 4.4$ ) and neutral ( $\mathrm{pH}$ 6.0) $\alpha$-mannosidase activities in various sources were determined by the following methods. Plasma, leukocyte, and cultured skin fibroblast extracts were diluted 10-fold in Mcllvaine's citrate-phosphate buffer (17), pH 4.4 and 6.0. Hepatic tissue was homogenized in distilled water $(1: 2, w / v)$, centrifuged at $30,000 \times g$ for $25 \mathrm{~min}$, and the supernatant assayed for enzymatic activity. The standard reaction mixture contained $300 \mu \mathrm{l} 1 \mathrm{mM}$ 4-methylumbelliferyl- $\alpha$-D-mannopyranoside (49) in citrate-phosphate buffer, $\mathrm{pH} 4.4$ or $\mathrm{pH} 6.0$, and $100 \mu \mathrm{l}$ of enzyme source. Leukocytes, cultured skin fibroblast and hepatic supernatants, and column fractions (100 $\mu \mathrm{l}$ of the $2.0-\mathrm{ml}$ fractions) were incubated for $30 \mathrm{~min}$, and plasma for $1 \mathrm{hr}$ at $37^{\circ}$. The reactions were terminated by the addition of $4.6 \mathrm{ml} 0.1 \mathrm{M}$ ethylenediamine, $\mathrm{pH}$ 11.4. Fluorescence was measured in a Turner model 111 fluorometer with an excitation wave length of $365 \mathrm{~nm}$ and an emission wave length of $450 \mathrm{~nm}$ and compared with 4-methylumbelliferone as a standard. Under these assay conditions, the rates of the enzyme reaction were linear with respect to time and protein concentration for each enzyme source.

For studies with metal ions, the reaction mixture was modified to contain $50 \mu$ l of enzyme source, $50 \mu \mathrm{l}$ of the appropriate metal ion $\left(\mathrm{CoSO}_{4}, \mathrm{ZnSO}_{4}\right.$ or $\left.\mathrm{MnCl}_{2}\right)$ in distilled water, and $300 \mu \mathrm{l}$ substrate in the appropriate buffer and then assayed as described above. Zinc and copper concentrations were determined in liver extracts from normal and mannosidosis tissues which were prepared as described for enzyme assay, according to standard techniques $(42,43)$.

The activities of other lysosomal hydrolases were determined in various sources with the appropriate artificial substrate according to the following methods: total $\alpha$ - and $\beta$-galactosidases (12), $\beta$-glucuronidase (48), total $\beta$-hexosaminidase (13), $\alpha$-L-iduroni- dase (18), arylsulfatase A (4), and $\alpha$-L-fucosidase (25). Protein concentrations were determined according to the method of Lowry (28).

The $\alpha$-mannosidase isozymes in normal human liver and mannosidosis liver obtained at autopsy were resolved by ion exchange chromatography. Liver $(2.0 \mathrm{~g})$ was homogenized in distilled water $(1: 4, w / v)$, centrifuged at $30,000 \times g$ for $25 \mathrm{~min}$, and the supernatant $(5 \mathrm{ml})$ was chromatographed on DEAE-cellulose (Whatman DE 52) (50), essentially by the method of Ikonne $e t$ al. (23).

Electrophoresis of partially purified $\alpha$-mannosidases A, B, and $\mathrm{C}$ and tissue extracts was performed on cellulose acetate gels (Cellogel, $350 \mu \mathrm{m}, 16$ by $17 \mathrm{~cm}$ ) (51) according to general procedures (15) with the following modifications for these isozymes. Electrophoresis was carried out in $0.04 \mathrm{M}$ potassium phosphate buffer, $\mathrm{pH} 7.3$, at $4^{\circ}$ with the electrophoresis tank on ice. Gels were prerun at $0.88 \mathrm{ma} / \mathrm{cm}$, constant current, for $20 \mathrm{~min}$; then samples $(5-10 \mu 1$ containing 3.5-6.5 nmol/hr) were applied with capillary micropipets and allowed to equilibrate for $10 \mathrm{~min}$. Constant current $(0.88 \mathrm{ma} / \mathrm{cm})$ was then applied; the duration of the electrophoretic run was $5 \mathrm{hr}$. The gel was removed from the tank and incubated for $1 \mathrm{~min}$ in $1.5 \mathrm{mM} 4$-methylumbelliferyl- $\alpha$-D-mannopyranoside in $0.1 \mathrm{M}$ citrate-phosphate buffer, $\mathrm{pH}$ 4.5. The gel was removed, gently blotted with filter paper, and placed in a moist chamber consisting of two glass plates separated by a border of felt strips saturated with water. The chamber was incubated at $37^{\circ}$ for $40 \mathrm{~min}$. Bands of fluorescence were developed by placing the gel in $0.17 \mathrm{M}$ glycine-carbonate buffer, $\mathrm{pH} 10.7$, for 2 min. The gel was blotted with filter paper and again placed in the moist chamber; the bands of enzymatic activity were viewed under long wave length ultraviolet light and photographed immediately.

\section{RESULTS}

\section{DIAGNOSTIC ENZYME DETERMINATIONS}

Table 2 shows the levels of acidic and neutral $\alpha$-mannosidase activities in plasma, isolated peripheral leukocytes, and cultured skin fibroblasts from five homozygotes with mannosidosis, their obligate heterozygous parents, and normal individuals. In each enzyme source from the homozygotes, there was a marked deficiency of $\alpha$-mannosidase activity at $\mathrm{pH} 4.4$, whereas the activity at $\mathrm{pH} 6.0$ was normal, with the exception of leukocytes, which demonstrated reduced neutral activities (29). The levels of acidic and neutral enzymatic activities obtained for the obligate heterozygotes were within the normal range; their ratios of acidic $\alpha$-mannosidase activity to total $\beta$-hexosaminidase activity at $\mathrm{pH}$ 4.4 in plasma and leukocytes from the parents of homozygotes $1-5$ were within the respective ranges calculated for normal individuals and did not discriminate the heterozygous state (29). The arylsulfatase A, $\alpha$-L-fucosidase, $\alpha$ - and $\beta$-galactosidase, $\beta$-glucuronidase, $\beta$-hexosaminidase $\mathrm{A}$ and $\mathrm{B}$, and $\alpha$-L-iduronidase activities in leukocytes and cultured skin fibroblasts from the homozygotes with mannosidosis were all within normal control ranges.

\section{MORPHOLOGIC STUDIES}

Approximately $80 \%$ of the lymphocytes in the peripheral blood smear contained 15-20 sharply defined, clear cytoplasmic vacuoles as shown in Figure 2. The vacuoles were not arranged in any particular array and essentially occurred wherever the cytoplasm was most abundant. The bone marrow smears contained numerous foamy macrophages, measuring approximately $40-50 \mu \mathrm{m}$ in diameter, which occurred both singly and in small groups as shown in Figure $3 A$. Generally, the nucleus was centrally or slightly eccentrically located. The appearance of the cytoplasm varied slightly in different macrophages; in some cells, the contents appeared as closely packed, sharply defined, clear vacuoles similar to those found in the lymphocytes. In other macrophages there 
Table. 2. Acidic and neutral $\alpha$-mannosidase activities in various sources from homozygotes and heterozygotes for mannosidosis and normal individuals ${ }^{1}$

\begin{tabular}{|c|c|c|c|c|c|c|}
\hline \multirow[b]{2}{*}{ Source } & \multicolumn{2}{|c|}{ Plasma, $\mathrm{nmol} / \mathrm{hr} / \mathrm{ml}$} & \multicolumn{2}{|c|}{ Leukocytes, nmol/hr/mg protein } & \multicolumn{2}{|c|}{$\begin{array}{l}\text { Cultured skin fibroblasts, } \\
\text { nmol/hr/mg protein }\end{array}$} \\
\hline & pH 4.4 & $\mathrm{pH} 6.0$ & pH 4.4 & $\mathrm{pH} 6.0$ & pH 4.4 & $\mathrm{pH} 6.0$ \\
\hline \multicolumn{7}{|l|}{ Family 1} \\
\hline \multicolumn{7}{|l|}{ Homozygote 1} \\
\hline$M L$ & 0.15 & 36.3 & 0.18 & 1.9 & $<0.01$ & 11.9 \\
\hline \multicolumn{7}{|c|}{ Heterozygotes $^{2}$} \\
\hline$J L$ & 3.75 & 38.5 & 75.0 & 30.0 & & \\
\hline$R L$ & 7.35 & 37.3 & 125 & 39.2 & & \\
\hline \multicolumn{7}{|l|}{ Family 2} \\
\hline \multicolumn{7}{|c|}{ Homozygotes 2-5 } \\
\hline$G G$ & 0.30 & 35.5 & 0.80 & 6.2 & & \\
\hline$J G$ & 0.18 & 46.5 & 0.84 & 5.5 & & \\
\hline$M a G$ & 0.02 & 49.0 & 0.91 & 4.5 & & \\
\hline$M e G$ & 0.15 & 34.5 & 0.52 & 3.5 & & \\
\hline \multicolumn{7}{|c|}{ Heterozygotes $^{2}$} \\
\hline$H G$ & 5.50 & 33.2 & 45.9 & 11.4 & & \\
\hline$E G$ & 6.50 & 43.5 & 35.4 & 5.23 & & \\
\hline Normal mean & 12.3 & 30.9 & 83.2 & 24.4 & 166 & 58.4 \\
\hline \multirow[t]{2}{*}{ (Range) } & $(3.5-$ & $(13.5-$ & $(22.8-$ & $(9.2-$ & $(36.3-$ & $(13.7-$ \\
\hline & 35.6) & 127) & 153) & 536) & 483) & 184) \\
\hline$n$ & 40 & 40 & 14 & 14 & 21 & 21 \\
\hline
\end{tabular}

${ }^{1}$ Enzymatic activities determined using 4-methylumbelliferyl- $\alpha$-D-mannopyranoside as substrate as described in Materials and Methods.

${ }^{2}$ The heterozygous individuals were the parents of the respective homozygotes.

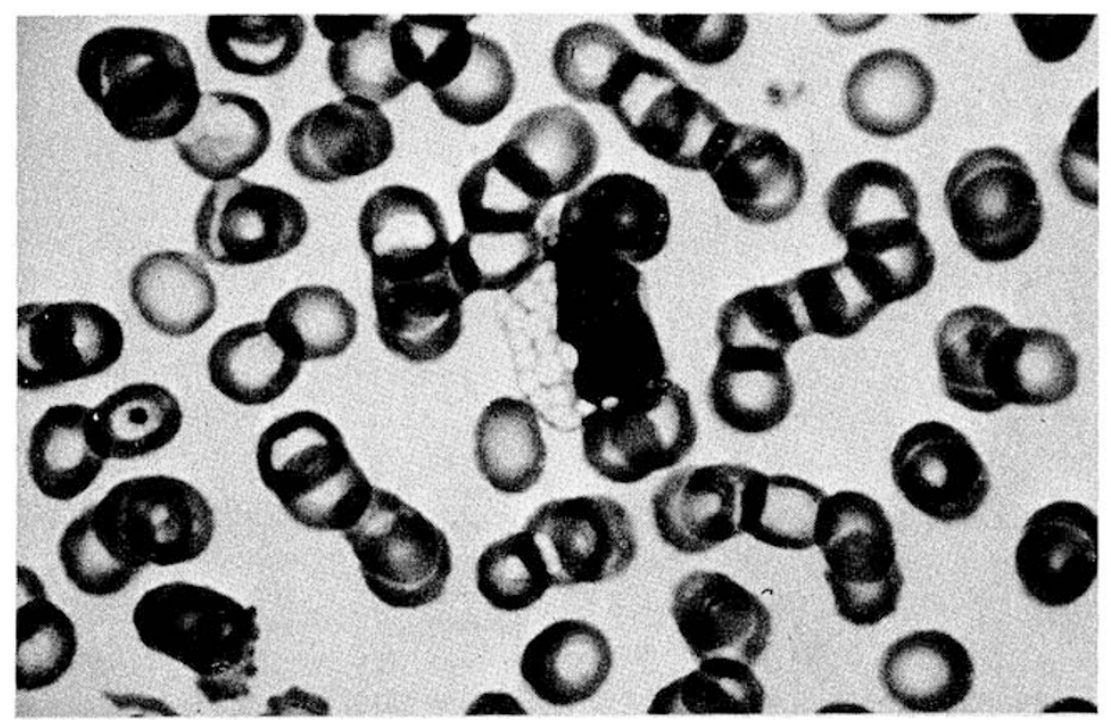

Fig. 2. Peripheral blood lymphocyte containing numerous clear, sharply defined cytoplasmic vacuoles (Wright's-Giemsa stain, $\times 1000$ ).

appeared to be a fusion of the vacuoles and a loss of their clear outlines. The macrophages in which several vacuoles appeared fused usually had a rim of sharply defined vacuoles at the periphery of the cytoplasm.

All histochemical stains were negative except for periodic acid-Schiff which reacted positively only at the junction of the fused vacuoles in bone marrow macrophages. On ultrastructural examination, all marrow macrophages exhibited vacuolar structures, most containing amorphous, osmophilic inclusion materials as shown in Figure 3, $B$ and $C$.

Examination of hepatic tissue obtained by percutaneous biopsy revealed enlarged hepatocytes with multiple clear, periodic acidSchiff negative vacuoles in their cytoplasm. Ultrastructural examination revealed numerous single membrane-bound vacuolar structures, presumably lysosomes, in the cytoplasm of almost all hepatic cells; these structures contained an abnormally accumu- lated, amorphous matrix-material with occasional membranous and/or filamentous structures.

A complete neuropathologic examination was performed within $1 \mathrm{hr}$ after death. The brain and spinal cord were not remarkable on gross examination. Histologic examination of the central nervous system, however, revealed striking neuronal storage in almost all neurons. The affected neurons were ballooned in varying degrees with either watery or finely granular cytoplasm as shown in Figure 4. The dorsal spinal, trigeminal, and paravertebral sympathetic ganglion cells were similarly affected. On ultrastructural examination, the cytoplasm of the affected neurons was often packed with storage vacuoles which were limited by a single membrane (Fig. 5). The storage vacuoles were remarkably electron-lucent or watery, and contained sparsely dispersed reticulogranular material, a few fine vacuoles, and varying amounts of fine fibrils in stacks. The size and contents of the vacuoles varied considerably in different 


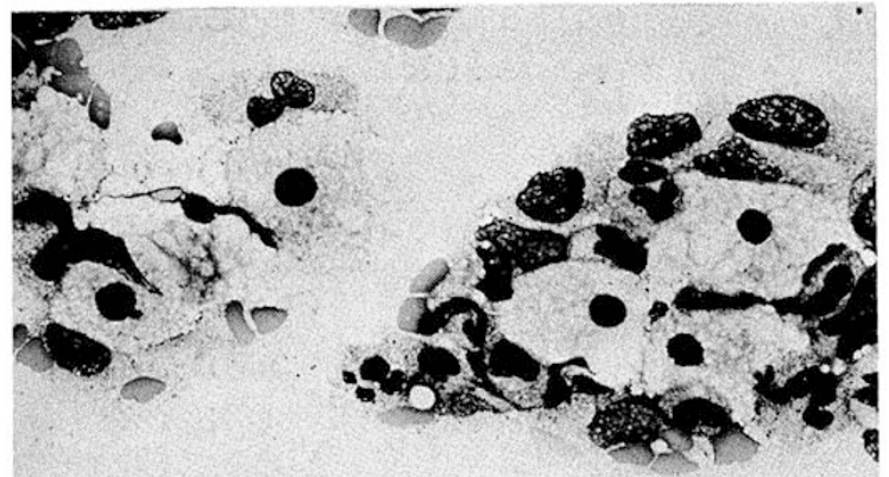

A
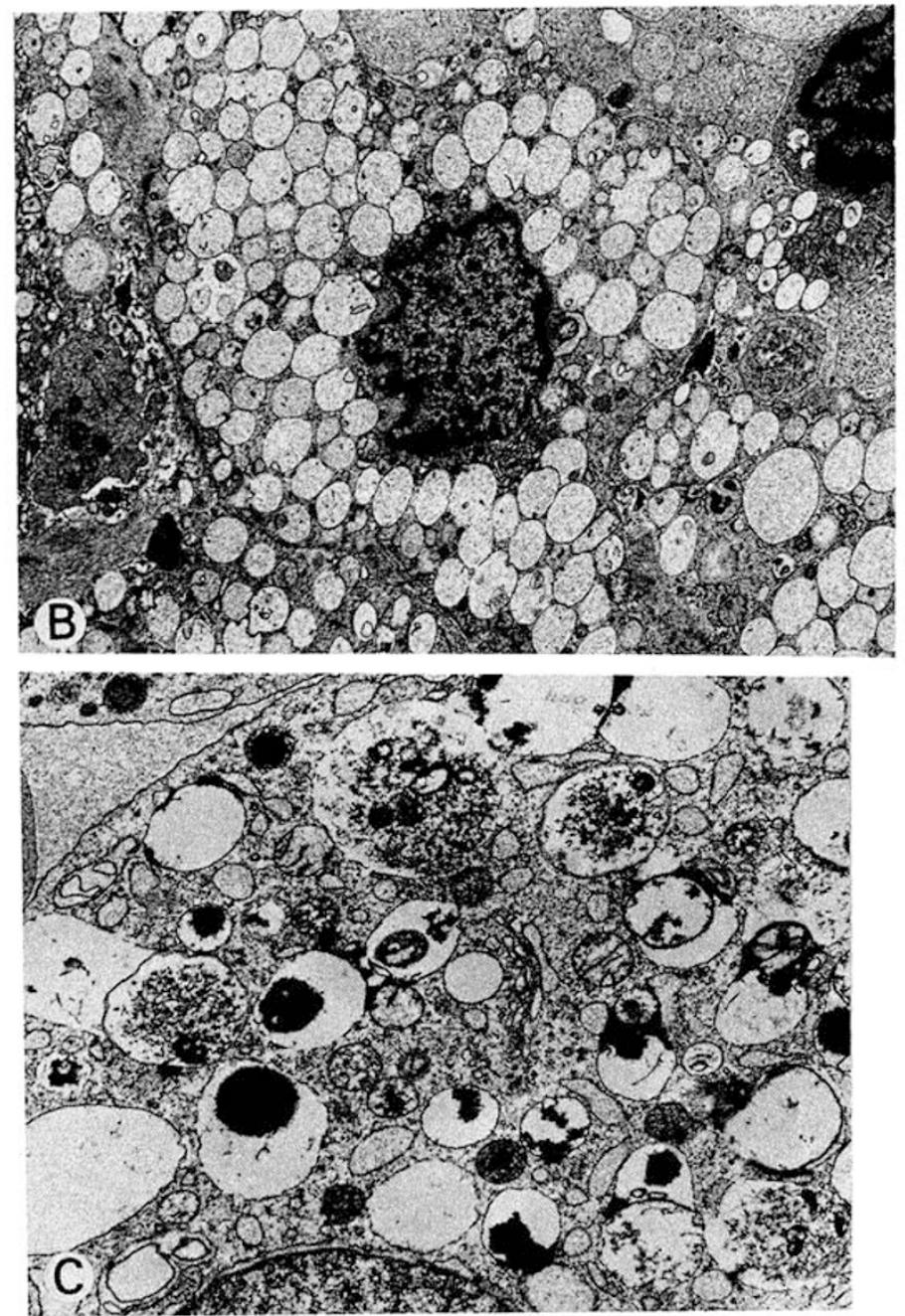

Fig. 3. $A$ : bone marrow smear showing numerous foamy macrophages (Wright's-Giemsa stain, $\times 400$ ). B: electron photomicrograph of a bone marrow macrophage showing numerous cytoplasmic vacuoles, a few containing some amorphous material (uranyl acetate and lead citrate, $x$ 5,600). $C$ : electron photomicrograph showing abundant amorphous debris in cytoplasmic vacuolar structures in a bone marrow macrophage $(x$ $13,800)$.

groups of neurons and the vacuoles were often fused or confluent. Detailed description of the pathologic findings will be reported elsewhere (44).

\section{IMMUNOLOGIC STUDIES}

The results of the neutrophil function evaluations of homozygote 1 , including chemotaxis, phagocytosis, and bacterial killing and
NBT reduction studies are summarized in Table 3. A profound defect in leukocyte response to chemotactic attraction was observed, whereas the mechanism for random migration was intact. Phagocytosis, as measured by bacterial killing studies, revealed slower phagocytosis by the patient's neutrophils than by control neutrophils. The NBT response in unstimulated neutrophils was normal and there was a normal increase in the NBT reduction on exposure to endotoxin (Table 3). Lymphocyte studies revealed $58 \%$ $\mathrm{B}$ cells and $42 \% \mathrm{~T}$ cells. Lymphocyte transformation studies showed a $20 \%$ of normal response to purified phytohemagglutinin and a $25 \%$ of normal response to concanavalin $\mathrm{A}$. In addition, the levels of IgG and IgE were slightly lower than the lower limit of the respective normal ranges for age.

\section{BIOCHEMICAL STUDIES}

Effect of $\mathrm{pH}$ and Substrate Concentration. The effect of $\mathrm{pH}$ on total $\alpha$-mannosidase activities in leukocytes and liver extracts from normal individuals revealed an optimum of $\mathrm{pH} 4.4$ in both sources, in agreement with previously reported values $(3,20,29,37)$. In contrast, a marked deficiency of activity at pH 3.5-5.0 was observed in these sources from homozygote $I$ with mannosidosis.

Figure $6 \mathrm{~A}$ shows the relationship between substrate concentration and $\alpha$-mannosidase activities, assayed at $\mathrm{pH} 4.4$, in leukocyte and liver extracts from a normal individual and homozygote $l$ with mannosidosis. Using the synthetic substrate, 4-methylumbelliferyl- $\alpha$-D-mannopyranoside, the acidic $\alpha$-mannosidase activity was saturated at a substrate concentration of about $2.5 \mathrm{mM}$ in both sources from the normal individual. A striking finding was the presence of detectable levels of acidic $\alpha$-mannosidase activity in these sources from the homozygote with mannosidosis which could not be saturated within the solubility range of the substrate. Apparent $\mathrm{K}_{\mathrm{m}}$ values for $\alpha$-mannosidase activity as determined from Lineweaver-Burk plots were $1.1 \mathrm{mM}$ for normal liver (Fig. $6 B$ ) and $0.9 \mathrm{mM}$ for normal leukocytes (Fig. $6 C$ ). In contrast, the apparent $\mathrm{K}_{\mathrm{m}}$ values in the homozygote with mannosidosis were extremely difficult to calculate; the apparent $\mathrm{K}_{\mathrm{m}}$ was estimated at $15.4 \mathrm{mM}$ in liver extracts.

Effect of Inhibitors. To rule out the possible existence of endogenous inhibitors of acidic $\alpha$-mannosidase activity in homozygote $I$ with mannosidosis, the acidic $\alpha$-mannosidase activity in 1:1 mixtures of both liver and leukocyte extracts from normal

Table 3. Polymorphonuclear function studies

\begin{tabular}{lcr}
\hline & Homozygote l & Control \\
\hline Chemotaxis (chemotactic index ${ }^{1}$ ) & 9 & \\
Random migration & 15 & 102 \\
$\quad$ Response to chemotactic attractant & & \\
Phagocytosis and bacterial killing ${ }^{2}$ (no. of & & \\
$\quad$ colonies) & & \\
Staphylococcus aureus & 650 & 640 \\
0 min & 710 & 170 \\
30 min & 290 & 54 \\
60 min & 120 & 18 \\
120 min & 1,000 & 960 \\
Escherichia coli & 180 & 38 \\
0 min & 80 & 56 \\
30 min & 52 & 2 \\
60 min & & \\
$\quad$ 120 min & & \\
Nitroblue tetrazolium reduction (\% cells & 10 & 9 \\
$\quad$ with blue formazan) & 27 & 24 \\
Unstimulated & & \\
Stimulated with endotoxin & & \\
\hline
\end{tabular}

${ }^{1}$ The chemotactic index was calculated as described in Materials and Methods.

${ }^{2}$ The bacteria-neutrophil ratio was $1: 1$. 


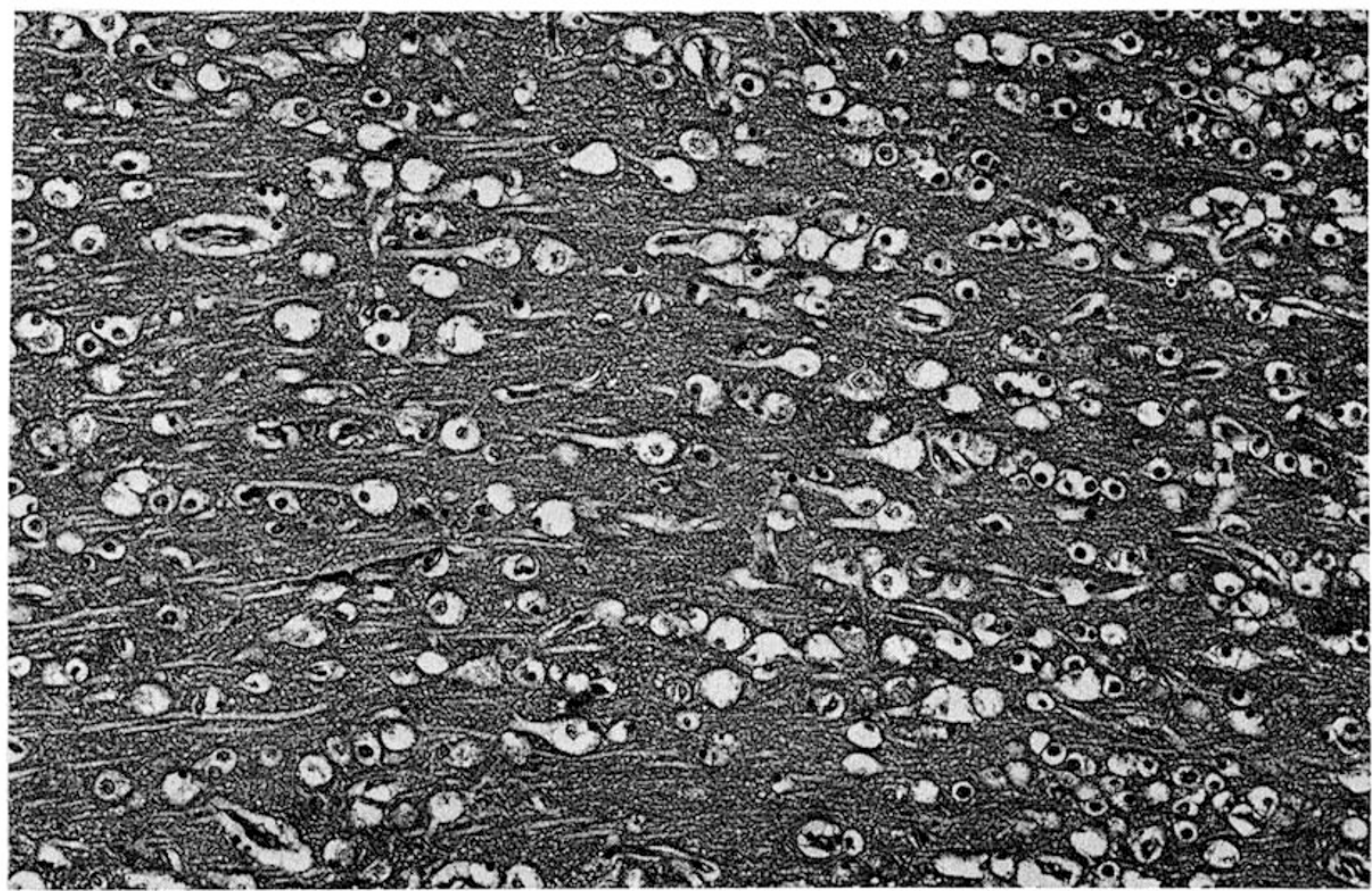

Fig. 4. Cerebral cortex: all of the neurons are ballooned and their cytoplasm is watery or clear (azocarmine stain, $\times 160$ ).

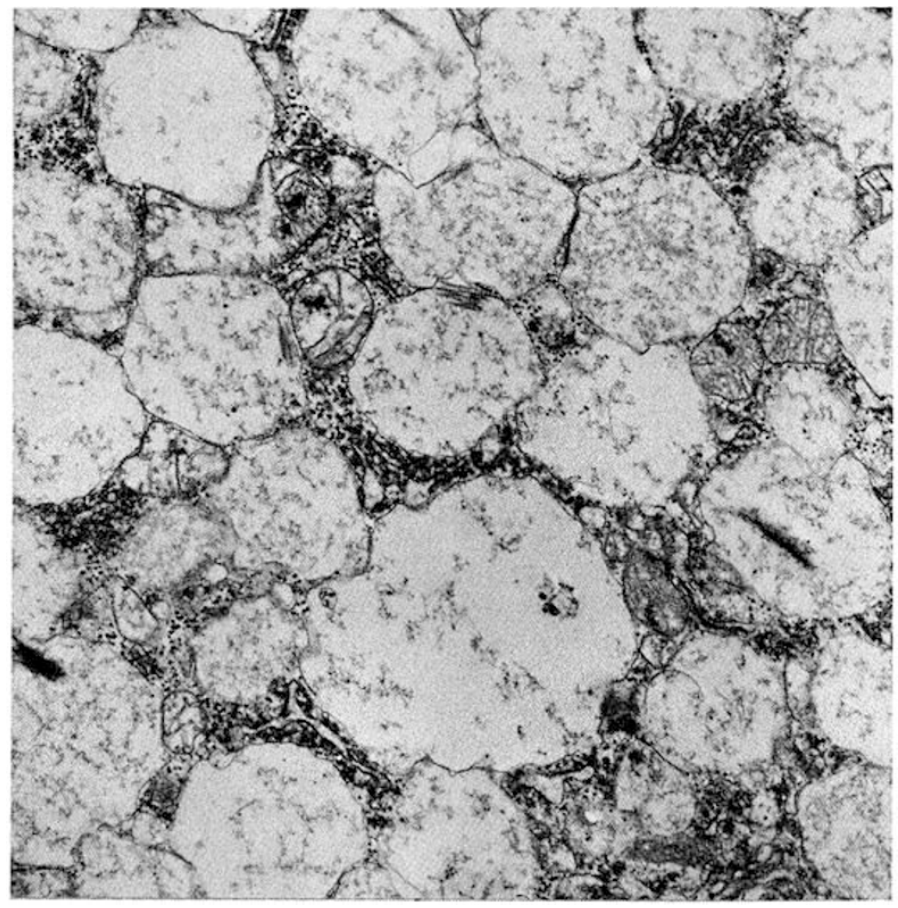

Fig. 5. Ventral horn cell of the spinal cord. The cytoplasm is packed with electron-lucent, single membrane-bound vacuoles which contain fine reticulogranular material and occasional stacks of fine fibrils (uranyl acetate and lead citrate, $\times 17,000)$.

individuals and the homozygote was determined. The observed activity in each mixture approximated the expected average of the activities in the normal and enzyme-deficient sources.

Effect of $\mathrm{ZnSO}_{4}, \mathrm{CoSO}_{4}$, and $\mathrm{MnCl}_{2}$. Figure $7 \mathrm{~A}$ shows the differential effects of increasing concentrations of zinc and cobalt ions on the acidic $\alpha$-mannosidase activity in liver extracts from homozygote $I$ and an age-matched normal individual. Zinc stimulated the acidic activity in normal liver to about $150-190 \%$ of initial activity at $\mathrm{ZnSO}_{4}$ concentrations between 0.01 and $5.0 \mathrm{mM}$ with maximal stimulation at $2.5 \mathrm{mM}$. In contrast, the acidic $\alpha$-mannosidase activity from the mannosidosis homozygote was only slightly stimulated to approximately $115 \%$ of initial activity at all concentrations from $0.01-10.0 \mathrm{mM} \mathrm{ZnSO}_{4}$. Whereas cobalt inhibited acidic $\alpha$-mannosidase activity in normal liver at all concentrations studied, a marked stimulation of the residual acidic activity in the homozygote was observed at final concentrations from $0.01 \mathrm{mM}$ to $8.0 \mathrm{mM}$, with maximal stimulation, $280 \%$ of initial activity, at $1 \mathrm{mM} \mathrm{CoSO} \mathrm{m}_{4} \cdot \mathrm{MnCl}_{2}$ was found to inhibit the acidic activities in normal and mannosidosis liver extracts; at 5.0 $\mathrm{mM}$, both activities were inhibited to approximately $30 \%$ of initial activity.

Figure $7, B$ and $C$, shows the effect of $2.5 \mathrm{mM} \mathrm{ZnSO}_{4}$ and 1.0 $\mathrm{mM} \mathrm{CoSO}{ }_{4}$ on the $\mathrm{V}_{\text {max }}$ and apparent $\mathrm{K}_{\mathrm{m}}$ values of the acidic activity in the normal and mannosidosis liver extracts as determined by Lineweaver-Burk plots. Zinc significantly lowered the apparent $\mathrm{K}_{\mathrm{m}}$ value of the acidic activity in normal liver (from 1.2 to $0.24 \mathrm{mM}$ ), whereas this metallic ion had little effect on the values for mannosidosis hepatic activity (from 15.4 to $12.3 \mathrm{mM}$ ). Unlike zinc, cobalt had its major effect on the acidic activity in the mannosidosis liver extract, lowering the apparent $\mathrm{K}_{\mathrm{m}}$ from 15.4 to $3.9 \mathrm{mM}$, whereas the apparent $\mathrm{K}_{\mathrm{m}}$ for the normal activity was increased from 1.2 to $1.9 \mathrm{mM}$.

As an internal control, the endogenous concentrations of zinc and copper in the liver extracts from the homozygote with mannosidosis and normal individuals were determined by atomic absorption spectroscopy. Compared with the concentration in a normal age-matched extract, the levels of zinc were higher in the homozygote, 4.8 and $28.6 \mu \mathrm{g} / \mathrm{g}$ wet weight, respectively. When expressed as the ratio of zinc to copper, the values for the mannosidosis and normal liver extracts were 13.0 and 7.5, respectively.

In leukocytes from all the homozygotes, zinc and cobalt stimulated both the residual acidic and neutral activities as shown in Table 4. In leukocytes from normal individuals the mean acidic activity was stimulated by zinc whereas cobalt was inhibitory; the mean neutral activity was stimulated both by zinc and cobalt ions.

Differential effects of these ions also were observed on the plasma acidic and neutral activities from the homozygotes compared with those from normal individuals. As shown in Table 4, the residual acidic activities from the homozygotes were stimulated by both zinc and cobalt; in contrast, zinc stimulated and cobalt inhibited the mean acidic activity from normal individuals. The 

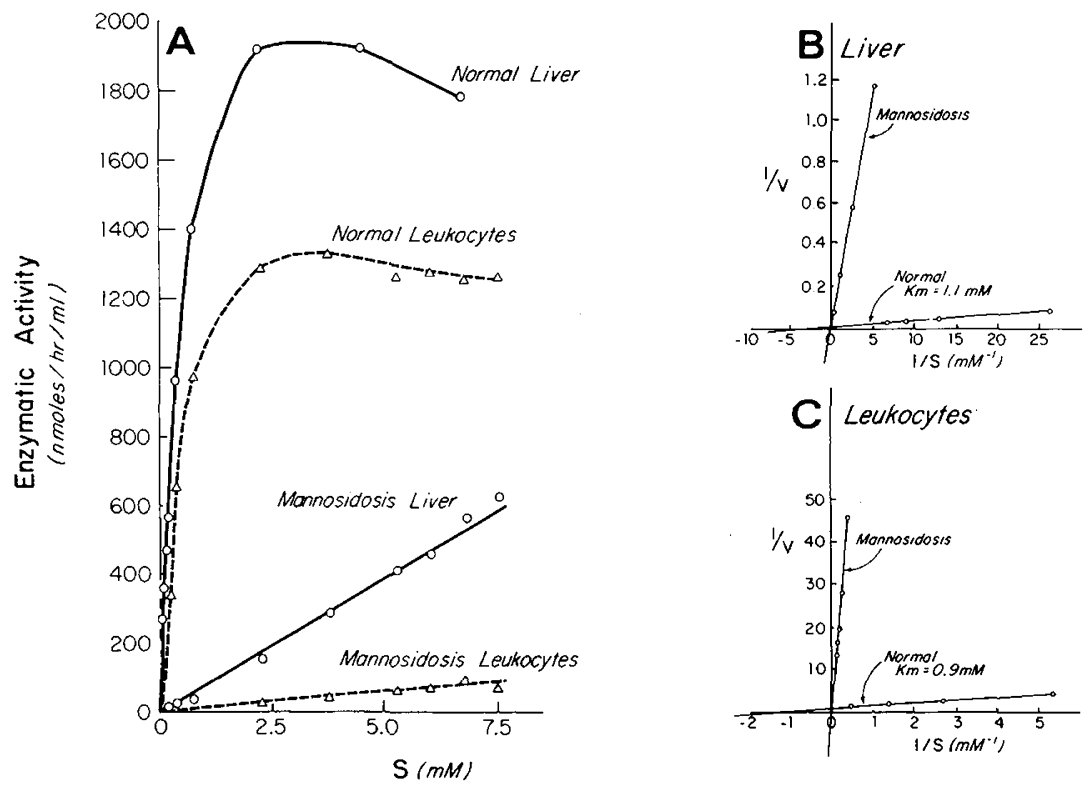

Fig. 6. $A$ : effect of substrate concentration on acidic $\alpha$-mannosidase activities in liver and leukocyte extracts from a homozygote with mannosidosis and a normal individual. Lineweaver-Burk plots of acidic $\alpha$-mannosidase activities in liver $(B)$ and leukocyte extracts $(C)$ from indicated sources.
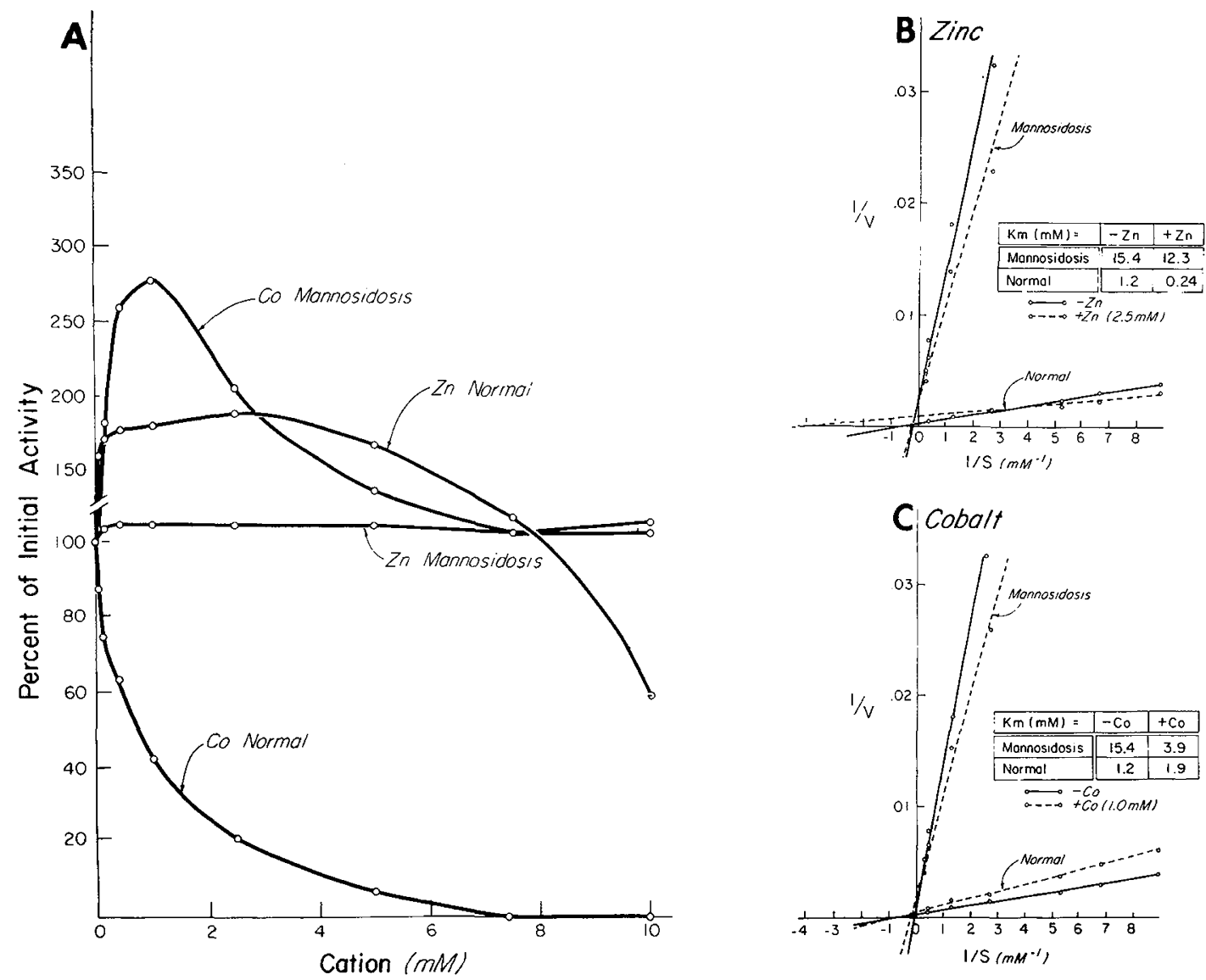

Fig. 7. $\mathrm{A}$ : effect of $\mathrm{ZnSO}_{4}$ and $\mathrm{CoSO}_{4}$ on acidic $\alpha$-mannosidase activities from indicated hepatic sources. Lineweaver-Burk plots of acidic $\alpha$-mannosidase activities in liver extracts from indicated sources in the presence and absence of $(B) 2.5 \mathrm{mM} \mathrm{ZnSO}_{4}$ and $(C) 1.0 \mathrm{mM} \mathrm{CoSO}$.

neutral activities from the homozygotes and normal individuals were essentially unaffected by either cation.

Resolution and Purification of $\alpha$-Mannosidase Isozymes. Three peaks of $\alpha$-mannosidase activity, A, B, and C, were observed after chromatography of normal liver extract on DEAE-cellulose as shown in Figure 8. The A and $\mathrm{B}$ isozymes were maximally detected at $\mathrm{pH} 4.4$, whereas the $\mathrm{C}$ isozyme was most active at $\mathrm{pH} 6.5$; low levels of A and B activity were also detected at $\mathrm{pH}$ 6.5. The $\mathrm{A}$ isozyme was eluted with the initial buffer wash and the $B$ and $C$ isozymes at $0.06 \mathrm{M}$ and $0.12 \mathrm{M}$ concentrations, respectively, on the linear $\mathrm{KCl}$ gradient. In contrast, when a liver extract from homozygote 1 was subjected to anion exchange chromatography, the activities of the A and B isozymes were detected, but at markedly low levels, whereas the $\mathrm{C}$ isozyme was eluted at the 
same salt concentration and with activity comparable to that of the normal C isozyme (Fig. 8). However, the residual B activity was eluted as a broad peak in a position between the normal liver $\mathrm{B}$ and $\mathrm{C}$ isozymes. These findings were consistent with our observations of residual acidic $\alpha$-mannosidase activities in crude leukocyte and liver extracts which could not be saturated with substrate (Fig. 6).

Further purification of the $\alpha$-mannosidase isozymes was achieved by differential ammonium sulfate precipitation followed by combined conventional and "oligo-affinity" (concanavalin A-Sepharose) chromatography $(11,22)$. By these procedures, normal hepatic $\alpha$-mannosidase A and B isozymes were purified about 150 - and 550 -fold with yields of $2 \%$ and $13 \%$, respectively, based on their initial $\mathrm{pH} 4.4$ activities. The neutral $\alpha$-mannosidase $\mathrm{C}$ was purified about 60 -fold with a $31 \%$ recovery based on the $\mathrm{pH}$
6.5 activity in the crude extract. Using these methods, the residual $\alpha$-mannosidase $\mathrm{A}$ and $\mathrm{B}$ activities from hepatic tissues from homozygote $l$ with mannosidosis were also purified. The partially purified residual activities had apparent $K_{m}$ values which were more than 50 times greater than those observed for the partially purified normal A and B isozymes; these residual activities were stimulated by cobalt and manganese cations which inhibited the activities of the normal $\mathrm{A}$ and $\mathrm{B}$ isozymes. The $\mathrm{C}$ isozymes purified from both sources had identical kinetic properties and similar responses to metal ions. The characterization of the physical and kinetic properties of the partially purified normal and residual activities will be reported elsewhere (22).

Electrophoresis of $\alpha$-Mannosidase Isozymes. Figure 9 shows that electrophoresis on cellulose acetate gel at $\mathrm{pH} 7.3$ distinctly separated the $\alpha$-mannosidase A, B, and C isozymes which were

Table 4. Effect of zinc and cobalt on acidic and neutral $\alpha$-mannosidase activities in leukocytes and plasma from homozygotes with mannosidosis and normal individuals

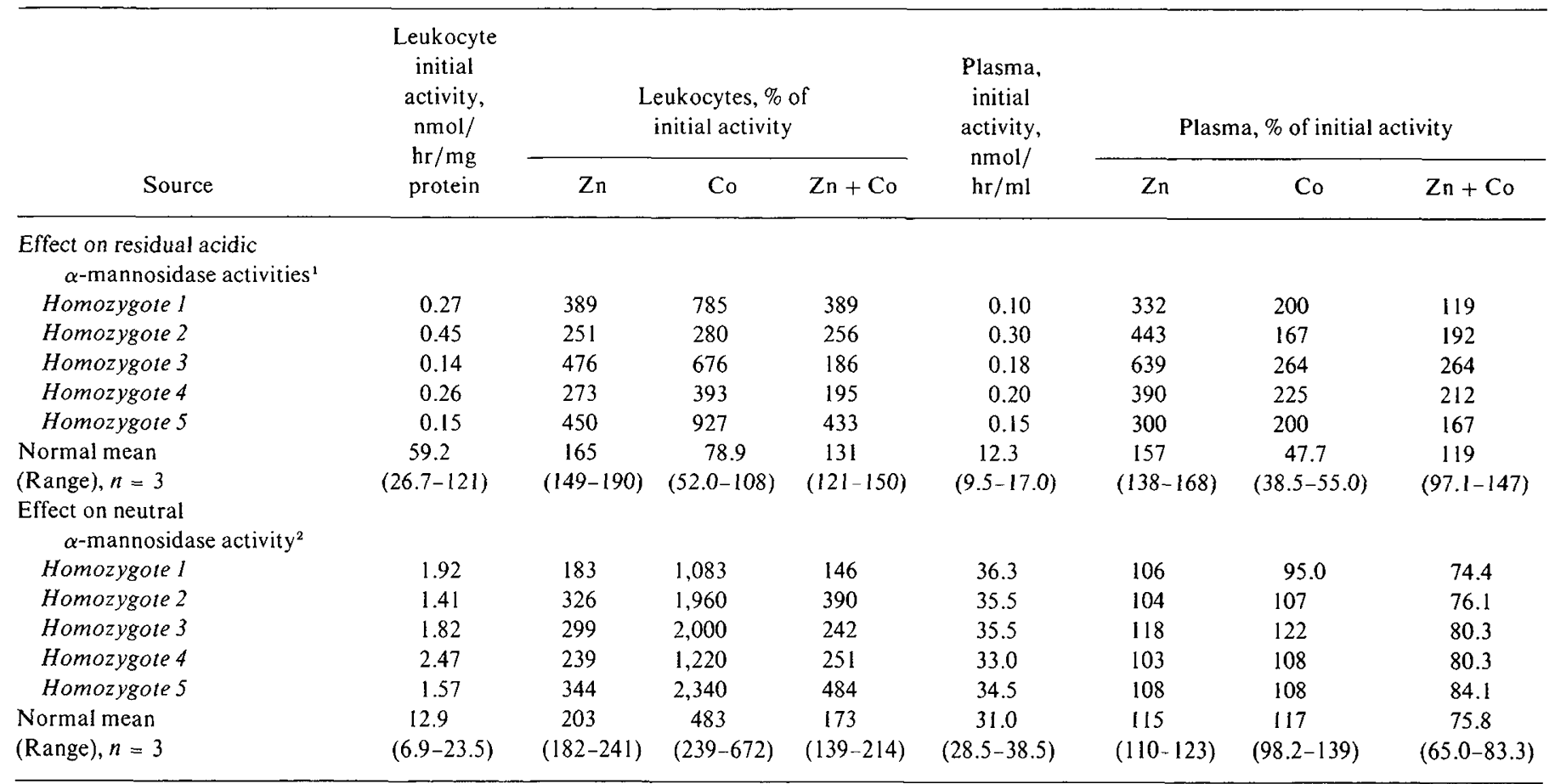

${ }^{1}$ Enzymatic activity assayed at $\mathrm{pH} 4.4$ in the presence of no metal ions, $2.5 \mathrm{mM} \mathrm{ZnSO}_{4}, 1.0 \mathrm{mM} \mathrm{CoSO}_{4}$, and $2.5 \mathrm{mM} \mathrm{ZnSO}_{4}+1.0 \mathrm{mM} \mathrm{CoSO}_{4}$.

${ }^{2}$ Enzymatic activity assayed at $\mathrm{pH} 6.0$ in the presence of no metal ions, $2.5 \mathrm{mM} \mathrm{ZnSO}_{4}, 1.0 \mathrm{mM} \mathrm{CoSO}_{4}$, and $2.5 \mathrm{mM} \mathrm{ZnSO}_{4}+1.0 \mathrm{mM} \mathrm{CoSO}_{4}$.

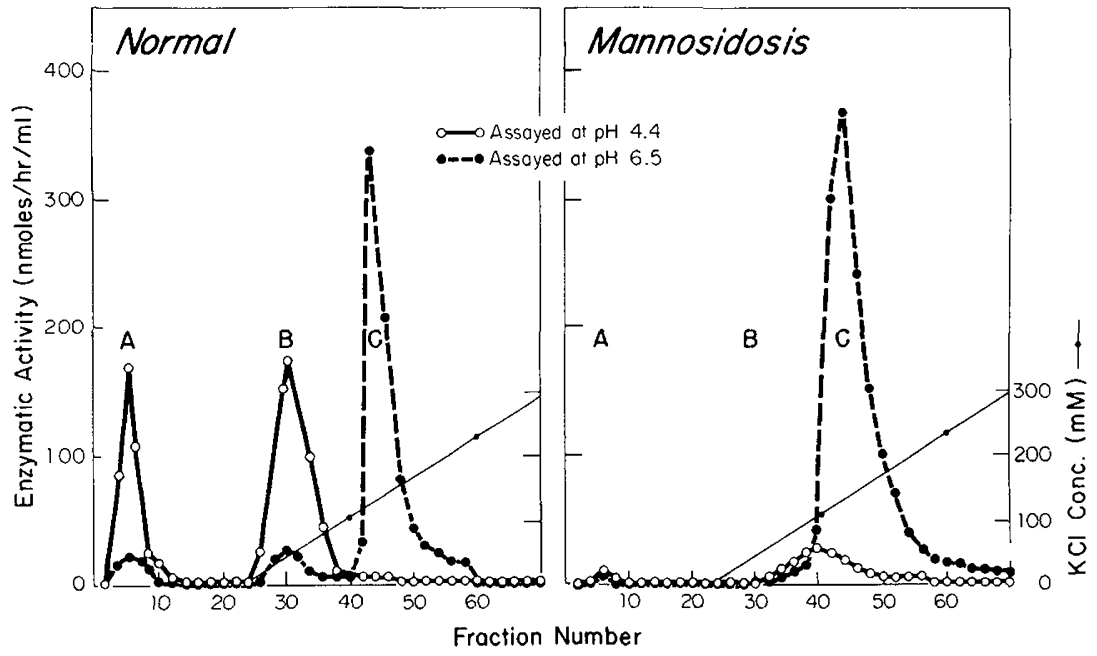

Fig. 8. Elution profile from the DEAE-cellulose chromatography of $\alpha$-mannosidase $\mathrm{A}_{\curvearrowright} \mathrm{B}$, and $\mathrm{C}$ isozymes in normal and mannosidosis liver. For details, see Materials and Methods. 


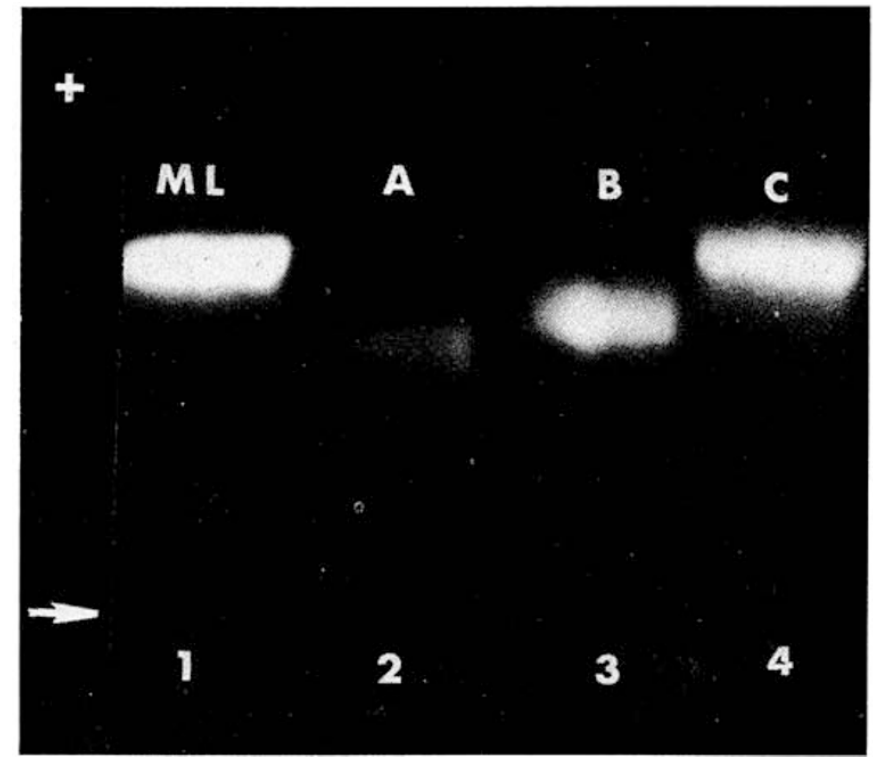

Fig. 9. Fluorescent bands of enzymatic activity after electrophoresis on cellulose acetate gel and staining with 4-methylumbelliferyl- $\alpha$-D-mannopyranoside. Lane 1: liver from the homozygote with mannosidosis (1:3 $\mathrm{w} / \mathrm{v}$ extract); lanes 2,3 , and 4 : partially purified normal human liver $\alpha$-mannosidase A, B, and C isozymes, respectively. Arrow: point of application.

partially purified from normal human liver. The B isozyme migrated between the $\mathrm{A}$ isozyme and the more electronegative $\mathrm{C}$ isozyme. In a liver extract from homozygote 1 with mannosidosis, a single band of activity was visible which was comparable in mobility to partially purified, normal hepatic $\alpha$-mannosidase $C$; the levels of residual A and B activities were not sufficient for detection in this system.

\section{DISCUSSION}

Since the original clinical and biochemical delineation of mannosidosis by Öckerman (33) in 1967, only 18 enzymatically diagnosed homozygotes have been reported in the world literature. Presumably, many patients have been misdiagnosed since the phenotypic features, as well as hematologic and radiologic findings, resemble those of the mucopolysaccharidoses. Thus, suspect patients should be confirmed biochemically. Our studies demonstrate that the enzymatic diagnosis of suspect homozygotes can be made reliably using plasma, isolated leukocytes, or cultured skin fibroblasts assayed carefully at the appropriate acidic pH (Table 2 ). The recent demonstration that total urinary mannose may be unreliable because of the wide variability in glycoprotein excretion in normal individuals (46) underscores the necessity for measurement of acidic $\alpha$-mannosidase activities rather than the levels of urinary mannose $(32,33)$.

Unfortunately, the enzymatic identification of heterozygotes for mannosidosis has been difficult $(1,14)$, as evidenced by our results (Table 2). Even when the ratio of $\alpha$-mannosidase to total $\beta$-hexosaminidase activities at $\mathrm{pH} 4.4$ is calculated, the values do not always discriminate heterozygotes as previously suggested (29). Thus, multiple determinations of acidic $\alpha$-mannosidase activity in several different sources may be required for heterozygote identification. The difficulty in heterozygote detection is unusual among the lysosomal storage diseases and suggests a unique interaction of the mutant and active gene products or associated cofactors in vivo.

The immunologic studies of the mannosidosis homozygote revealed significant abnormalities of neutrophil function; these included a depressed chemotactic responsiveness and impaired phagocytosis of bacteria. However, endotoxin-stimulated neutro- phils showed normal NBT reduction, suggesting normal oxidative responsiveness in these cells. In addition, there were depressed lymphocyte responses to $\mathrm{T}$ cell mitogens and phytohemagglutinin and concanavalin $\mathrm{A}$. These findings suggest defective function of leukocyte plasma membrane-mediated processes.

It is tempting to speculate that the leukocyte abnormalities result from abnormal mannose catabolism. Partially degraded oligosaccharides, glycopeptides, and glycoproteins with terminal $\alpha$-D-mannose residues may be bound to the leukocyte plasma membranes as well as accumulated in their lysosomes. In addition, circulating mannose-rich substrates may interfere with leukocyte function. These abnormal metabolites may lead to impaired neutrophil responses to chemotactic attractants, impaired neutrophil bactericidal mechanisms, and decreased lymphocyte binding of phytomitogens by altering leukocyte membrane surface structure or charge (16). The chemical alteration of the receptors for these membrane-recognition processes may account for the observed abnormalities of leukocyte function and the increased susceptibility to recurrent bacterial and viral infections which characterize the clinical course of this disease.

A most intriguing aspect of our kinetic studies was the demonstration of residual acidic $\alpha$-mannosidase activity in crude liver and leukocyte extracts from homozygote 1 with mannosidosis. Using the synthetic substrate, 4-methylumbelliferyl- $\alpha$-D-mannopyranoside, this acidic activity could not be saturated in either enzyme source. The apparent $\mathrm{K}_{\mathrm{m}}$ values for the residual hepatic and leukocytic activities, estimated from Lineweaver-Burk plots (Fig. 6), were more than 15 and 20 times greater than those calculated for the respective normal sources. These results are supported by our preliminary observations that the $K_{m}$ values for the partially purified residual A and B isozymes were more than 50 times greater than those calculated for the partially purified normal hepatic isozymes $(11,22)$. In agreement with these findings, a residual acidic $\alpha$-mannosidase activity with altered kinetics and increased heat lability has been recently described in crude extracts of cultured skin fibroblasts from four unrelated homozygotes with mannosidosis (5).

The effects of zinc (stimulation) and cobalt (inhibition) on acidic $\alpha$-mannosidase activity in normal human liver extracts $(10,37)$ and mannosidosis extracts $(21)$ have been reported recently. In addition, the specific activity of $\alpha$-mannosidase at $\mathrm{pH} 5.0$ has been correlated directly with the zinc content of various rat tissues (43) and $\alpha$-mannosidase purified to homogeneity from the jack-bean has been shown to be a zinc metalloenzyme (42), indicating the importance of zinc to this enzymatic activity. Our studies also demonstrated a stimulatory effect of zinc and an inhibitory effect of cobalt ions on acid $\alpha$-mannosidase activity in normal liver extracts. In the presence of $2.5 \mathrm{mM} \mathrm{ZnSO}_{4}$ and $1.0 \mathrm{mM} \mathrm{CoSO}_{4}$, the $V_{\max }$ and apparent $K_{m}$ values estimated for the acidic activity in normal liver extracts from Lineweaver-Burk plots were altered; the apparent $\mathrm{K}_{\mathrm{m}}$ values were decreased in the presence of zinc and slightly increased when cobalt was present in the crude extract. However, a differential effect was observed when these metal ions were incubated in the liver extracts from the homozygote with mannosidosis. The apparent $\mathrm{K}_{\mathrm{m}}$ values for the residual acidic activity were decreased slightly with zinc and markedly with cobalt. In contrast to the significant effect of zinc on the kinetics of normal acidic activity, the minimal effect of zinc on the residual acidic activity may be related to the physical properties of the mutant isozymes (e.g., metal binding capacity) or possibly to the presence of higher endogeneous concentrations of zinc in the extract as well as in other sources from the mannosidosis homozygote.

Zinc and cobalt markedly stimulated the residual acidic activities in the plasma and both the residual acidic and neutral activities in the leukocytes from the homozygotes (Tables 2 and 4). These in vitro studies demonstrated that $1.0 \mathrm{mM}$ cobalt enhanced the residual acidic and neutral activities in leukocytes from homozygotes more than the $2.5 \mathrm{mM}$ zinc concentration. The cobalt 
enhancement of this residual acidic activity in the homozygote (compared with the inhibiting effect of cobalt on the acidic activity in leukocytes from normal individuals) may be an assay artifact, presumably due to partial activity detected at $\mathrm{pH} 4.4$ of the neutral component, which was markedly stimulated (10-fold) by cobalt. However, this effect of cobalt was not observed on the neutral activity in plasma from homozygotes and normal individuals (Table 4). It is intriguing to note that the molecular defect in mannosidosis altered both the acidic and neutral activities in leukocytes, but only the acidic activities in plasma and hepatic tissues from homozygotes, whereas the obligate heterozygotes had completely normal levels of neutral leukocytic activity (Table 2). It is possible that the residual acidic activity in patients with mannosidosis might be increased following the administration of appropriate trace metals based on the in vitro characterization of the specific response of a particular family's mutation to metal ion supplementation. The effectiveness of this therapeutic approach should be evaluated in Angus calves with mannosidosis, an animal model of the human enzymatic deficiency disease (36) and in cultured skin fibroblasts obtained from the patient before in vivo trials.

Three major components of $\alpha$-mannosidase activity in normal human liver were resolved by ion exchange chromatography on DEAE-cellulose (Fig. 8) and electrophoresis on cellulose acetate gels (Fig. 9) in agreement with previously reported findings $(9,10$, $29,37,38,40$ ). Two isozymes, $\alpha$-mannosidases $\mathrm{A}$ and $\mathrm{B}$, had optimal activities at $\mathrm{pH} 4.4$ and the third isozyme, $\alpha$-mannosidase $\mathrm{C}$, had an optimum at $\mathrm{pH}$ 6.5. Differential ammonium sulfate precipitation followed by conventional and affinity chromatographic (40) procedures has already resulted in significant purification of these isozymes from normal human liver for subsequent physical and kinetic characterization $(11,22)$.

Electrophoresis of the liver extract from homozygote $l$ with mannosidosis revealed only one band of activity which coelectrophoresed with the $\alpha$-mannosidase $\mathrm{C}$ isozyme partially purified from normal liver; similar results have been previously reported in tissues $(38)$ and cultured skin fibroblasts $(6,45)$ from homozygotes with mannosidosis. Although no residual acidic activities were detected electrophoretically in the mannosidosis liver extract, ion exchange chromatography revealed the presence of residual acidic activities; the residual $\mathrm{A}$ isozyme was eluted in a position corresponding to that of normal $\alpha$-mannosidase $\mathrm{A}$ whereas the residual $B$ activity was eluted at a slightly more electronegative position than that of normal B isozyme.

Our studies of the acidic $\alpha$-mannosidase isozymes in the crude tissue extracts and in the partially purified preparations have provided intriguing data concerning the residual acidic astivities in tissues from the homozygote with mannosidosis. These findings suggest that the enzymatic defect in patient $l$ may have resulted from a missense mutation in the structural gene coding for the acidic $\alpha$-mannosidase activities. Apparently, this mutation resulted in a gene product which rendered the enzyme protein for the $\mathbf{B}$ isozyme more electronegative and altered the kinetic and metal binding properties of both acidic isozymes. Although this hypothesis is appealing, clearly, the implications of these studies, particularly with crude extracts, require further documentation.

From a clinical perspective, mannosidosis appears to present in at least two major forms: type I homozygotes (e.g., homozygote l) have severe disease with hepatosplenomegaly, severe recurrent infections, and early demise whereas type II homozygotes (e.g., homozygotes 2-5 and cases 15-17, Table 1) have a milder course characterized primarily by hearing loss, mental retardation, milder dysostosis multiplex, and survival into adulthood. Indeed, careful characterization of the residual activities purified from various sources from type I and type II homozygotes may provide insight into the marked clinical differences among these patients (Table 1) which suggest heterogeneity of the genetic defects in different families with mannosidosis. Further investigation of the kinetic, physical, and immunologic properties of highly purified $\alpha$-man- nosidase isozymes with natural as well as synthetic substrates will be required to elucidate the molecular and genetic interrelationships among the normal isozymes and the molecular pathology of the residual activities in mannosidosis.

\section{SUMMARY}

The clinical and laboratory features of a $3 \frac{1}{2}$-year-old patient with mannosidosis are described and compared with those of all the cases reported in the world's literature. The clinical diagnosis of our patient was established by the observation of vacuolated peripheral lymphocytes, foamy bone marrow macrophages, lysosomal inclusions in hepatic cells obtained by percutaneous biopsy, and the deficient activities of $\alpha$-D-mannosidases $\mathrm{A}$ and $\mathrm{B}$ in the plasma, isolated peripheral leukocytes, and cultured skin fibroblasts. Immunologic investigations revealed leukocyte functional defects which presumably account for the susceptibility to intercurrent infections which characterize the clinical course of this disorder. An intriguing finding was the presence of residual hepatic $\alpha$-D-mannosidase A and B activities which were less than $5 \%$ of normal mean hepatic activities; the residual activities were stimulated more than $21 / 2$-fold when assayed in the presence of $1.0 \mathrm{mM}$ $\mathrm{CoSO}_{4}$ in vitro, suggesting that cobalt and/or zinc supplementation might be of therapeutic value in patients with this enzymatic defect.

\section{REFERENCES AND NOTES}

1. Autio, S., Norden, N. E., Öckerman, P. A., Riekkinen, P., Rapola, J., and Louhimo, T.: Mannosidosis: Clinical, fine-structural and biochemical findings in three cases. Acta Paediat. Scand., 62: 555 (1973).

2. Aylsworth, A. S., Taylor, H. A., Stuart, C. M., and Thomas, G. H.: Mannosidosis: Phenotype of a severely affected child and characterization of $\alpha$-mannosidase activity in cultured fibroblasts from the patient and his parents. J. Pediat., 88 : 814 (1976).

3. Avila, J. L., and Convit, J.: Characterization and properties of $\alpha$-D-mannosidase of human polymorphonuclear leukocytes. Clin. Chim. Acta, 47: 335 (1973).

4. Baum, H., Dodgson, K. S., and Spencer, B.: The assay of arylsulfatases A and B in human urine. Clin. Chim. Acta, 4: 453 (1959).

5. Beaudet, A. L., and Nichols, B. L., Jr.: Residual altered $\alpha$-mannosidase in human mannosidosis. Biochem. Biophys. Res. Commun. 68: 292 (1976).

6. Booth, C. W., Chen, K. K., and Nadler, H. L.: Mannosidosis: Clinical and biochemical studies in a family of affected adolescents and adults. J. Pediat., 88: 821 (1976).

7. Boyum, A.: Separation of leukocytes from blood and bone marrow. Scand. J. Clin. Lab. Invest. (Suppl. 97), 21: 1 (1968).

8. Brunning, R. D., and Parkin, J.: Ultrastructural studies of parallel tubular arrays in human lymphocytes. Amer. J. Pathol. 78: 59 (1975).

9. Carroll, M.. Dance, N., Masson, P. K., Robinson, D., and Winchester, B. G.: Human mannosidosis-the enzymic defect. Biochem. Biophys. Res. Commun., 49: 579 (1972).

10. Chester, M. A., Lundblad, A., and Masson, P. K.: The relationship between different forms of human $\alpha$-mannosidase. Biochim. Biophys. Acta, 391: 341 (1975).

11. Desnick, R. J.: Unpublished results.

12. Desnick, R. J., Allen, K. Y., Desnick, S. J., Raman, M. K., Bernlohr, R. W., and Krivit, W.: Fabry's disease: Enzymatic diagnosis of hemizygotes and heterozygotes. Alpha-galactosidase activities in plasma, serum, urine and leukocytes. J. Lab. Clin. Med., 8I: 157 (1973).

13. Desnick, R. J., Krivit, W., Snyder, P. D., Desnick, S. J., and Sharp, H. L.: Sandhoff's disease: Ultrastructural and biochemical studies. In: S. M. Aronson and B. W. Volk: Sphingolipids, Sphingolipidoses and Allied Disorders, p. 351 (Plenum Press, New York, 1972).

14. Farriaux, J. P., Legouis, I., Humbel, R., Dhondt, J. L., Richard, P., Strecker, G., Fourmaintraux, A., Ringel, J., and Fontaine, G.: La mannosidoses. Nouv. Presse Med., 4: 1867 (1975).

15. Fluharty, A. L., Lassila, E. L., Porter, M. $\Upsilon$., and Kihara, H.: The electrophoretic separation of human $\beta$-galactosidases on cellulose acetate. Biochem. Med., 5: 158 (1971).

16. Gallin, J. I., Durocher, J. R., and Kaplan, A. P.: Interaction of leukocyte chemotactic factors with the cell surface. I. Chemotactic factor-induced changes in human granulocyte surface charge. J. Clin. Invest., 55: 967 (1975)

17. Gomori, G.: Preparation of buffers for use in enzyme studies. Methods Enzymol., 1: 138 (1955).

18. Hall, C. W., and Neufeld, E. F.: $\alpha$-L-Iduronidase activity in cultured skin fibroblasts and amniotic cells. Arch. Biochem. Biophys., 158: 817 (1973)

19. Hill, H. R., Hogan, N. A., Mitchell, T. G., and Quie, P. G.: Evaluation of a cytocentrifuge method for measuring neutrophil granulocyte chemotaxis. J. Lab. Clin. Med., 86: 703 (1975). 
20. Hultberg. B.: Properties of $\alpha$-mannosidase in mannosidosis. Scand. J. Clin. Lab. Invest., 26: 155 (1970).

21. Hultberg, B., and Masson, P. K.: Activation of residual acidic $\alpha$-mannosidase activity in mannosidosis tissues by metal ions. Biochem. Biophys. Res. Commun., 67: 1473 (1975).

22. Ikonne, J. U., and Desnick, R. J.: Mannosidosis: Characterization of the enzymatic defect. (In preparation.)

23. Ikonne, J. U., Rattazzi, M. C., and Desnick, R. J.. Characterization of hex $S$, the major residual $\beta$-hexosaminidase activity in type $O G_{M_{2}}$ gangliosidosis (Sandhoff-Jatzkowitz disease). Amer. J. Hum. Genet., 27: 639 (1975).

24. Kjellman, B., Gamstorp, I., Brun, A., Ockerman, P. A., and Palmgren, B.: Mannosidosis: A clinical and histopathologic study. J. Pediat., 75: 366 (1969).

25. Leroy, J. G., Ho, M. W., MacBrinn, M. C., Zielke, K., Jacob, J., and O'Brien, J. S.: I-cell disease: Biochemical studies. Pediat. Res., 6: 752 (1972).

26. Loeb, H.: Personal communication.

27. Loeb, H., Tondeur, M., Toppet, M., and Cremer, N.: Clinical, biochemical and ultrastructural studies of an atypical form of mucopolysaccharidosis. Acta Paediat. Scand., 58: 220 (1969).

28. Lowry, O. H., Rosebrough, N. J., Farr. A. L., and Randall, R. J.: Protein measurement with the Folin phenol reagent. J. Biol. Chem., 193: 265 (1951).

29. Masson, P. K., and Lundblad, A.: Mannosidosis: Detection of the disease and of heterozygotes using serum and leucocytes. Biochem. Biophys. Res. Commun., 56: 296 (1974).

30. Mowat, A. G., and Baum, J.: Chemotaxis of polymorphonuclear leukocytes from patients with rheumatoid arthritis. J. Clin. Invest., 50: 2541 (1971).

31. Norden, N., Lundblad, A.. Svensson, S., Öckerman, P. A., and Autio, S.: A mannose-containing trisaccharide isolated from urines of three patients with mannosidosis. J. Biol Chem., 17: 6210 (1973).

32. Norden, N. E., Öckerman, P. A., and Szabo, L.: Urinary mannose in mannosidosis. J. Pediat., 82: 686 (1973).

33. Öckerman, P. A.: A generalized storage disorder resembling Hurler's syndrome. Lancet, ii: 239 (1967).

34. Öckerman, P. A.: Mannosidosis: Isolation of oligosaccharide storage material from brain. J. Pediat. 75: 360 (1969).

35. Park, B. H., Fikrig, S. M., and Smithwick, E. M.: Infections and nitroblue tetrazolium reduction by neutrophils. Lancet, ii: 532 (1968).

36. Phillips, N. C., Robinson, D., and Winchester, B. G.: Mannosidosis in Angus cattle: The enzymic defect. Biochem. J., 137: 363 (1974).

37. Phillips, N. C., Robinson, D., and Winchester, B. G.: Human liver $\alpha$-mannosidase activity. Clin. Chim. Acta, 55: 11 (1974).

38. Poenaru, L., and Dreyfus, J. C.: Electrophoretic heterogeneity of human $\alpha$-mannosidase. Biochim. Biophys. Acta, 303: 171 (1973).

39. Quie, P. G., White, J. G., Holmes, B., and Good, R. A.: In vitro bactericidal capacity of human polymorphonuclear luekocytes: Diminished activity in chronic granulomatous disease of childhood. J. Clin. Invest., 46: 668 (1967).

40. Robinson, D., Phillips, N. C., and Winchester, B.: Affinity chromatography of human liver $\alpha$-D-mannosidase. Fed. Eur. Biochem. Soc. Lett., 53: 110 (1975).
41. Sharp. H. L., and Desnick, R. J.: Sandhoff's disease: Diagnosis and evaluation by percutaneous liver biopsy. Gastroenterology, 60: 752 (1971).

42. Snaith, S. M.: Characterization of jack-bean $\alpha$-D-mannosidase as a zinc metalloenzyme. Biochem. J., 147: 83 (1975).

43. Snaith, S. M., Hay, A. G., and Levvy, G. A.: Relation between the $\alpha$-mannosidase activity and the zinc content of mammalian sex organs. J. Endocrinol, 50: 659 (1971).

44. Sung, J. H., Hayano, M., and Desnick, R. J.: Neuropathology of mannosidosis. J. Neuropathol. Exp. Neurol. (In press.)

45. Taylor, H. D., Thomas, G. H., Aylsworth, A., Stevenson, R. E., and Reynolds, C. W.: Mannosidosis: Deficiency of a specific $\alpha$-mannosidase component in cultured fibroblasts. Clin. Chim. Acta, 59: 93 (1975).

46. Tsay, G. C., Dawson, G., and Matalon, R.: Excretion of mannose-rich complex carbohydrates by a patient with $\alpha$-mannosidase deficiency (mannosidosis). J. Pediat.. 84: 865 (1974).

47. Tsay, G., Dawson, G., and Matalon, R.: Glycopeptide storage in skin fibroblasts cultured from a patient with $\alpha$-mannosidase deficiency. J. Clin. Invest., 56:711 (1975).

48. Woolen, J. W., and Walker, P. G.: The fluorimetric estimation of $\beta$-glucuronidase in blood plasma. Clin. Chim. Acta, 12: 659 (1965).

49. Research Products Incorporated, Elk Grove Village, Ill.

50. Reeve Angel, Clifton, N. J

51. Kalex Scientific, Manhasset, N. Y.

52. Informed consent for these studies was obtained from the parents of the homozygotes.

53. The authors wish to express their gratitude to Dr. J. G. Leroy for his expert clinical suggestions and fibroblast enzyme determinations and to Dr. L. Singer for the trace metal analyses. We also wish to thank Mr. Peter M. Anderson and Ms. Linda Walling for the electrophoretic studies, Mr. Mohanreddy Raman and Ms. Debra Seehausen for their skillful technical assistance, and Ms. Ardys Ferman for her expert clerical assistance.

54. Dr. R. J. Desnick is a recipient of National Institutes of Health Research Career Development Award KO4 AM 00042.

55. Dr. P. G. Quie is an American Legion Memorial Heart Research Professor.

56. These results were reported in part at the Twenty-Seventh Annual Meeting of the American Society of Human Genetics, Baltimore, Md., October 2-11, 1975, Amer. J. Hum. Genet., 27: 48A (1975).

57. This work was supported in part by a grant (1-273) from the National Foundation-March of Dimes; Grants AM 15174, AI 06931, and DE 01770 from the National Institutes of Health; Grant RR-400 from the General Clinical Research Center, Program of the Division of Research Resources, National Institutes of Health; and Grant 74-915 from the American Heart Association.

58. Requests for reprints should be addressed to: R. J. Desnick, Ph.D., M.D., Box 231 Mayo, University of Minnesota Hospitals, Minneapolis, Minn. 55455 (USA).

59. Accepted for publication June 8, 1976.
Airway resistance specific airway resistance thoracic gas volume

\title{
A Simplified Approach to the Measurement of Specific Airway Resistance
}

\author{
I. DAB AND F. ALEXANDER
}

Respiratory Physiology Department of the Astmacentrum, De Haan aan Zee, and Department of Pediatrics of the Free University of Brussels, Brussels, Belgium

\section{Extract}

A simple algebraic manipulation of known formulas leads to a direct expression for the specific airway resistance $\left(\mathbf{S R}_{\mathrm{aw}}\right)$ which precludes separate measurements of the airway resistance $\left(R_{a w}\right)$ and the thoracic gas volume (TGV). The equation is: $\mathbf{S R}_{\mathrm{aw}}=\operatorname{tg} \beta\left(\mathbf{P}_{\mathrm{Bar}}\right.$ $\left.-\mathbf{P}_{\mathrm{H}_{2} \mathrm{O}}\right) \mathbf{e}_{2}$, in which $\operatorname{tg} \beta$ stands for the relation between the plethysmographic box volume and pneumotachograph flow fluctuations; $\mathbf{P}_{\mathrm{Bar}}-\mathbf{P}_{\mathrm{H}_{2} \mathrm{O}}$ is the barometric pressure corrected for water vapor pressure at body temperature, and $e_{2}$ is a calibration for graphical units. Thanks to this new formula $\mathrm{SR}_{\mathrm{aw}}$ can now be easily measured with great precision and quickly calculated, even in the case of those children (Table 1) with whom this was not previously possible. No further cooperation is needed than breathing at a 